\title{
PEMBINAAN KOMPETENSI KEWIRAUSAHAAN KEPALA SEKOLAH MELALUI TRANSFORMASI PENGALAMAN DIRI DI KABUPATEN SIDOARJO
}

\author{
SAJI \\ Email: sajidelta21@gmail.com
}

\begin{abstract}
Abstrak
Salah satu kompetensi yang wajib dimiliki kepala sekolah adalah kewirausahaan. Lemahnya kompetensi kewirausahaan kepala sekolah binaan berdampak pada pengelolaan lulusannya yang tidak mencapai target seperti yang diharapkan. Pola pengelolaan lulusan di sekolah binaan selama ini terhenti pada output saja. Hal ini terbukti dari data penelusuran lulusan dari tahun 2009-2014 disekolah binaan, 81\% lulusannya menganggur. Permasalahan tersebut penulis atasi dengan bekal pengalaman dan jaringan kerja lintas sektor dengan melibatkan peran dunia usaha, dan industri. Strategi yang di gunakan nyata dan terukur, dengan contoh-contoh yang telah dirasakan keberhasilannya. Kondisi yang belum sesuai harapan penulis atasi dengan upaya pembinaan kompetensi kepala sekolah, melalui strategi transformasi pengalaman diri. Melalui strategi tersebut, penulis menularkan pengalamannya, membimbing kepala sekolah mengubah pola pengelolaan lulusan, yang tidak berhenti pada out put saja, tetapi dilanjutkan dengan program penyaluran sampai lulusannya mampu mandiri. Caranya dengan pendampingan dan fasilitasi, serta bimbingan, baik kelompok maupun individu. Kepala sekolah dilibatkan dalam praktek mendayagunakan peran serta masyarakat, belajar berkolaborasi membangun jaringan kerja lintas sektor, melalui kunjungan lapangan keberbagai dinas/intansi terkait. Langkah-langkahnya diawali dengan persiapan, studi lapangan mengunjungi beberapa perusahaan, promosi, dan koordinasi, penyaluran, serta monitoring dan tindak lanjut. Tingkat keberhasilan strategi terlihat pada adanya perubahan pola pengelolaan sekolah, yaitu: (1) kepala sekolah binaan mampu menyusun program dan tim penanganan lulusan, (2) peserta didik disiapkan secara lebih terarah pada kebutuhan dunia kerja, (3) dalam waktu 3 tahun 71,\% lulusan berhasil di salurkan di empat perusahaan, (4) kepala sekolah mampu mengubah lulusan dari tiga demensi berkarakter, kreatif, dan produktif, menjadi lulusan dengan empat dimensi yaitu, berkarakter, kreatif, dan produktif, serta mandiri di masyarakat. Dampaknya antara lain, (1) citra sekolah meningkat, dua sekolah binaan dalam akreditasi mendapat predikat A, (2) para pihak merasa bangga lulusannya berhasil, ( 3) stigma yang kurang baik pada lulusan berangsur berubah kearah yang positif oleh karena dengan memiliki pekerjaan lulusan berpenghasilan layak mampu hidup mandiri di masyarakat.
\end{abstract}

Kata Kunci: transformasi, pengalaman diri 


\section{PENDAHULUAN}

\section{A. Rasional}

Berdasarkan Peraturan Pemerintah nomor 74 tahun 2008 pengawas sekolah adalah guru pegawai negeri sipil yang diangkat dalam jabatan pengawas sekolah yang tugasnya melaksanakan pengawasan. Selanjutnya menurut Peraturan Menteri Pendayagunaan Aparatur Negara dan Reformasi Birokrasi nomor 14 Tahun 2016 tentang Perubahan atas Peraturan Menteri Pendayagunaan Aparatur Negara dan Reformasi Birokrasi nomor 21 Tahun 2010 tentang Jabatan Fungsional Pengawas Sekolah dan Angka Kreditnya Bab II Pasal 5 dinyatakan bahwa, tugas pokok pengawas sekolah adalah melaksanakan pengawasan akademik dan manajerial pada satuan pendidikan.

Dalam Peraturan Menteri Pendidikan Nomor 12 tahun 2007, tentang standar kompetensi pengawas sekolah, dinyatakan bahwa pengawas sekolah, harus memiliki minimal enam kompetensi yaitu, kompetensi kepribadian, supervisi manajerial, akademik, evaluasi pendidikan, penelitian, dan pengembangan, serta kompetensi sosial. Dimilikinya kompetensi tersebut diharapkan pengawas sekolah dapat melaksanakan tugas pokoknya dengan baik. Penulis selaku pengawas sekolah, memiliki pengalaman dalam mengelola pendidikan khusus yang berorientasi pada kebutuhan lingkungan.

Sejak tahun 2000 penulis telah melakukan penanganan lulusan melalui program penyaluran kerja yang diawali kerjasama dengan PT. First Medipharma di Jalan Raya Sumorame nomer 41 Candi Sidoarjo, yang ternyata hasilnya memuaskan, mampu mengantarkan lulusan mencapai kemandirian. Program penyaluran kerja ternyata sangat membantu lulusan dari berbagai SLB. Selanjutnya agar MoU, dan pembinaaan bisa dilakukan antar lembaga, maka pada tahun 2001 penulis mendirikan yayasan, sehingga jaringan kerjasama lintas sektor semakin luas.

Upaya penulis membimbing kepala sekolah bekerjasama dengan lintas sektor untuk menangani lulusan, berdampak pada peningkatkan kesejahteraan penyandang disabilitas diapresiasi positif oleh pemerintah. Pada puncak peringatan Hari Internasional Penyandang Cacat penulis dianugerahi penghargaan oleh Presiden Republik Indonesia berupa "Satya Lencana Kebaktian Sosial“ berdasarkan Surat Keputusan Presiden Republik Indonesia nomor 056/TK/Tahun 2008. Pemerintah menilai penulis telah berkontribusi dalam lapangan perikemanusiaan umumnya atau dalam suatu bidang perikemanusiaan tertentu, yaitu aktif dalam berbagai kegiatan sosial bagi penyandang cacat, menyalurkan kerja ke beberapa perusahaan, dan mendirikan yayasan, sekolah luar biasa, sehingga terbangun jaringan kerja sama lintas sektor, menjadi akses yang memudahkan penyandang disabilitas memperoleh lapangan pekerjaan. 

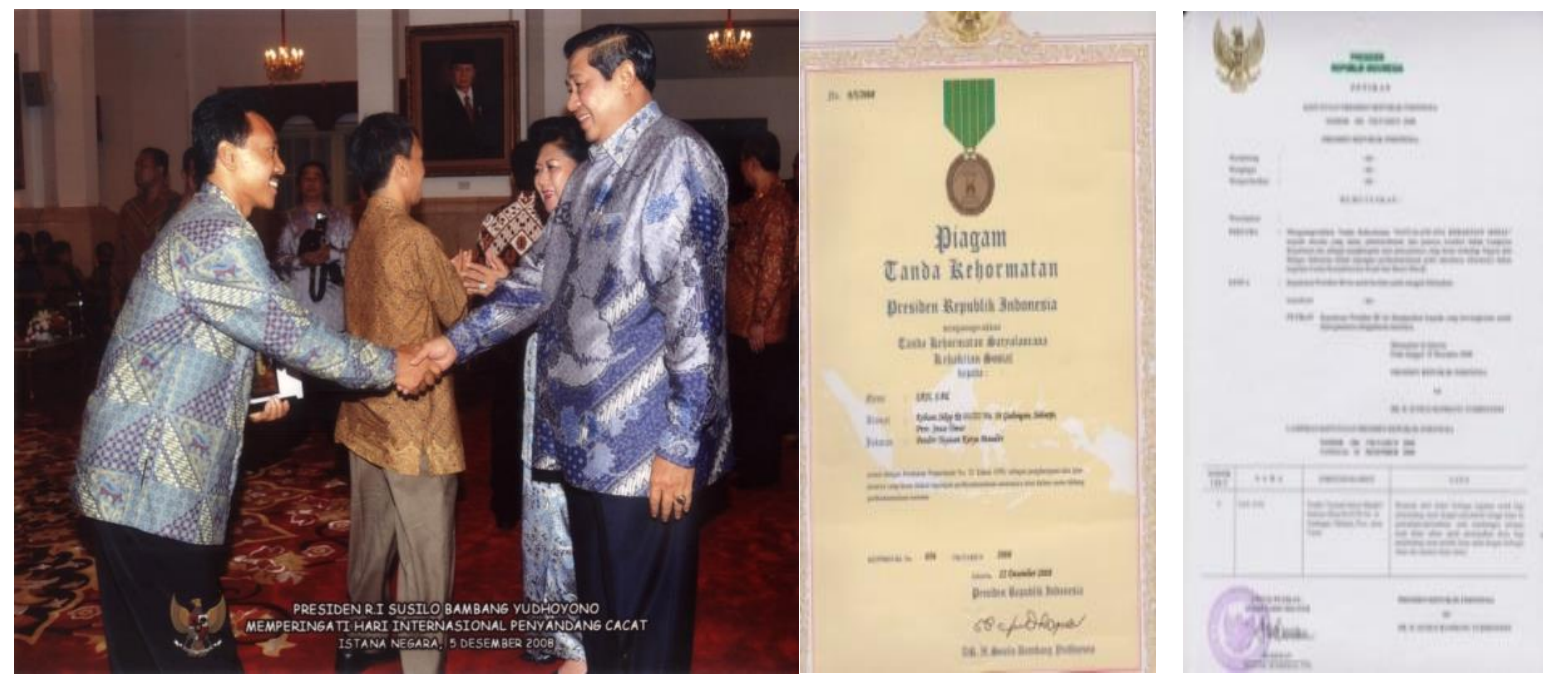

Gambar 1.1. Modalitas pengalaman, dan jaringan kerja lintas sektor

Keinginan untuk terus, membantu penyandang disabilitas, dan modalitas pengalaman, serta jaringan kerja lintas sektor yang telah terbangun berperan besar untuk membantu kepala sekolah mengatasi permasalahan khususnya penanganan lulusan. Berdasarkan hasil supervisi di sekolah binaan pada tahun pelajaran 2014/2015, permasalahan mendasar yang dampaknya cukup signifikan dalam pelayanan pendidikan yaitu: (1) proses pembelajaran belum memenuhi standar, (2) hasil, dan pemanfaatan lulusannya belum maksimal (81,1\% menganggur). Permasalahan tersebut muncul dipicu oleh dua faktor yaitu internal dan eksternal. Faktor internal, antara lain: standar kompetensi guru, sarana dan prasarana yang dimiliki sekolah binaan masih kurang memadai. Faktor eksternal terkait akses dan jaringan kerjasama antara sekolah dengan dunia kerja yang belum terbangun.

Strategi untuk mengatasi permasalahan tersebut adalah pembinaan kompetensi kewirausahaan kepala sekolah. Dasar pembinaan adalah Peraturan Menteri Pendidikan Nasional Nomor 13 Tahun 2007, tentang Standar Kompetensi Kepala Sekolah/Madrasah yang meliputi, kompetensi kepribadian, manajerial, supervisi, sosial dan kompetensi kewirausahaan. Dengan memiliki kompetensi kewirausahaan diharapkan kepala sekolah mampu berperan sebagai motor penggerak kemajuan sekolah, bekerja secara kreatif, menciptakan ide-ide baru, bekerja keras, berani menanggung resiko untuk mengubah keadaan menjadi lebih baik.

Pembinaan, dilakukan melalui bimbingan, pelatihan, dan pendampingan, serta fasilitasi kepala sekolah dan guru-guru di sekolah binaan, membantu peningkatan kualitas pembelajaran, pengelolaan input, proses, dan outputnya, menuju ke arah tercapainya standar, serta mendayagunakan peran serta dunia usaha dan industri dalam bingkai kerjasama lintas sektor.

Harapannya agar kepala sekolah dapat mengubah pola penanganan yang lebih baik, tidak membiarkan lulusan atau tidak hanya berhenti pada out put saja, tetapi dilanjutkan melalui program 
penyaluran sehingga menjadi lulusan dengan empat dimensi yaitu, berkarakter, kreatif, dan produktif, serta mandiri. Penulis memberi contoh kepala sekolah binaan bahwa hambatan yang ada pada peserta didik, bisa dijadikan kelebihan dengan cara memperkuat karakternya, yaitu menjadikan anak yang rajin bekerja ( dalam istilah jawa sregep/doyan gawean) membangun simpati, dan empati para pihak memprosikan anak berkebutuhan khusus dalam ekosistem yang inklusif. Melalui strategi transformasi pengalaman diri, permasalahan yang dihadapi sekolah, dapat diatasi sehingga pelayanan pendidikan dirasakan para pihak menjadi lebih baik.

\section{B. Penerapan Strategi Transformasi Pengalaman Diri}

Transformasi menjadi kunci dari sebuah perubahan, dimana pengalaman yang sudah penulis lakukan dapat dijadikan dasar acuan atau strategi untuk melakukan perubahan. Kata transformasi merupakan serapan dari kata transformation, (bahasa Inggris) yang artinya perubahan. Tentunya perubahan yang dimaksud adalah kearah yang lebih baik dari kondisi sebelumnya. Dikaitkan dengan permasalahan yang dihadapai kepala sekolah binaan pengalaman diri penulis relevan untuk digunakan sebagai dasar melakukan perubahan untuk mengatasi permasalahan.

Dasar pertimbangan pemilihan strategi transformasi pengalaman diri adalah: (1) penulis telah memilikinya, (1) dapat dilaksanakan secara bertahap dan berkelanjutan dalam tugas kepengawasan, (3) merupakan bagian dari tugas pokok penulis sebagai pengawas sekolah.

Penerapan strategi dilakukan dengan berbagai cara, secara bertahap, dan berkelanjutan melalui bimbingan kelompok, pendampingan, dan fasilitasi, penugasan, sampai praktek agar kepala sekolah mampu: (1) menyusun program, (2) meningkatkan kualitas proses pembelajaran untuk menyiapkan kompetensi peserta didik yang sesuai kebutuhan dunia kerja, (3) membangun akses yang memudahkan lulusan memperoleh pekerjaan, (4) mendayagunakan sumberdaya sekolah dan peran serta masyarakat, khususnya dunia usaha dan industri, maupun lintas sektor, menjalin kemitraan dan membuat jejaring untuk kemajuan sekolah.

Untuk belajar membangun jaringan kerja lintas sektor kepala sekolah diajak mengunjungi perusahaan, mendatangi kantor dinas, dan instasi terkait diantaranya kantor dinas tenaga kerja, dan kantor dinas sosial, serta kantor badan pemberdayaan perempuan Kabupaten Sidoarjo. Tujuannya agar kepala sekolah merasakan suasana kebatinan pengalaman diri penulis, sehingga pengalaman diri penulis dapat diterima, dan dimiliki. Penulis secara inten, mendiskusikan permasalahan sekolah untuk menyamakan pandangan sehingga pola pikir dan pola tindak antara kepala sekolah, dan pengawas ada kesamaan. Adanya perubahan pada diri 
kepala sekolah dalam meniru dan mengikuti pengalaman diri penulis maka, tercipta ruang konsultasi, dan diskusi- diskusi lanjutan untuk bersama-sama menemukan cara pemecahan masalah untuk peningkatan mutu pengelolaan.

Latihan kemandirian dilakukan dengan: (1) menumbuhkan jiwa wirausaha agar setiap kepala sekolah mampu mengerahkan segala daya upayanya menciptakan peluang untuk mengatasi masalah disekolahnya, (2) mendampingi dan memfasilitasi kepala sekolah agar mampu bertindak sebagai inisiator, fasilitator, kolaborator, promotor, sekaligus penjamin/broker, (3) mendorong kepala sekolah selain menjadi manajer, juga menjadi seorang entrepreneur, agar mampu menyiapkan kompetensi lulusannya mudah terserap diperusahaan yang menjadi potensi wilayah Kabupaten Sidoarjo sebagai daerah industri.

Penulis dalam berbagai kesempatan mendorong kepala sekolah mendayagunakan komite sekolah, dan perusahaan yang ada disekitar sekolah untuk melatih keberanian. Untuk memudahkan pelaksanaan strategi, dilakukan, pendampingan, dan fasilitasi, serta pembimbingan setahap, demi setahap untuk menguasai ketrampilan, dan pengetahuan, serta kepercayaan diri sehingga pada suatu saat kepala sekolah akan mampu melakukannya secara mandiri. Caranya membimbing sampai yang dibimbing bisa melakukan secara mandiri. Hal ini sejalan dengan pendapat (Prayitno \& Erman Amti: 2004). yang menyatakan bimbingan adalah proses pemberian bantuan yang dilakukan oleh orang yang ahli kepada seseorang atau beberapa orang individu, baik anak-anak, remaja, maupun dewasa agar orang-orang yang dibimbing dapat mengembangkan kemampuan dirinya sendiri dan mandiri.

Bimbingan, dan fasilitasi, serta pendampingan dilakukan agar kepala sekolah memiliki jiwa kemandirian, dan kemampuan bekerja keras, serta sikap pantang menyerah mencari solusi yang kreatif, dan inovatif, relevan dengan ciri utama wirausaha (Kemdiknas 2011) menyatakan bahwa lima ciri utama kewirausahaan yaitu, pantang menyerah, mencari solusi terbaik (kreatif memecahkan masalah), inovatif, pekerja keras, dan motivasinya kuat.

Dimilikinya jiwa kemandirian, dan motivasi yang kuat pada diri kepala sekolah diarahkan untuk belajar berkolaboari antara pengawas dengan kepala sekolah, maupun kepala sekolah dengan guru-gurunya untuk: (1) menyusun program, dan membentuk tim yang bertugas berdasarkan surat keputusan ( SK) dari kepala sekolah, (2) mendampingi dan memfasilitasi kepala sekolah dalam membuat jaringan kerja lintas sektor membangun akses untuk memudahkan penyaluran atau pemasaran produksi (output) sumber daya anak berkebutuhan khusus. Menurut penuturan semua kepala sekolah binaan, penyaluran atau pemasaran lulusan, merupakan bagian yang dirasakan paling sulit didalam proses pelayanan 
pendidikan. Berdasarkan kenyataan seperti itu maka, transformasi pengalaman diri dibutuhkan, dan dapat membantu kepala sekolah binaan.

Tahapan yang sulit, dan sangat penting dalam proses transformasi pengalaman diri adalah pembinaan dalam hal : (1) menyiapkan sikap mental agar tangguh menghadapi berbagai hambatan seperti penolakan, keraguan, ketakutan, kecurigaan, kelelahan, kekecewaan, bahkan diremehkan, (2) menyadari adanya fakta bahwa produk sumber daya dari pendidikan khusus (SLB), memang memiliki keterbatasan, tetapi juga memiliki banyak kelebihan, misalnya dalam bekerja lebih tekun, teliti, rajin, loyal, penurut, dan semangatnya tinggi, (3) mengemas sisi kelebihan lulusan sebagai kekuatan untuk dipromosikan karena perusahaan membutuhkan lulusan yang berkarakter bahkan beberapa perusahaan cenderung memilih lulusan dari sekolah luar biasa. Ketrampilan menurut penuturan pihak perusahaan mudah dilatihkan.

Setelah kepala sekolah binaan memiliki komitmen, dan motivasi yan kuat dalam menindak lanjuti informasi penyaluran lulusan, maka tahapan berikutnya adalah pendampingan dan fasilitasi agar kepala sekolah mampu berperan sebagai inisiator, fasilitator, kolaborator, promomotor, sekaligus penjamin/broker,

Kepala sekolah yang sudah mampu berperan sebagai inisiator dibantu untuk menjadi simbion berjejaring dengan perusahaan dalam bingkai kerja sama yang selama ini sudah dijalin oleh penulis ditindak lanjuti sehingga kerjasama yang saling menguntungkan antara perusahaan dan pihak sekolah terus terjaga. Simbiosis mutualisme yang diharapkan adalah perusahaan mendapatkan karyawan yang baik, sedangkan sekolah binaan lulusannya terserap sebagai karyawan di perusahaan.

Agar lulusan bisa terserap diperusahaan kepala sekolah diminta untuk mendata lulusannya. Ternyata sejak tahun 2009 lulusan di sekolah binaan belum tertangani. Menyikapi hal ini penulis membantu, dan mendampingi, serta memfasilitasi kepala sekolah, dan guru pendamping agar lulusan yang belum tertangani segera diikutkan program penyaluran. Penyaluran lulusan dari tahun 2009 sampai tahun 2014 menjadi prioritas, yang akhirnya berhasil dilakukan. Berhasilnya penyaluran lulusan tersebut dipicu adanya motivasi yang kuat dari kepala sekolah binaan, dan adanya jaringan kerja lintas sector khususnya perusahaan mitra kerja yayasan, serta dukungan orang tua siswa.

Yayasan Karya Mandiri sebagai lembaga yang berbadan hukum, didirikan untuk membangun jaringan kerja lintas sektor secara formal dengan dinas dan instansi terkait serta pembina dua sekolah luar biasa yaitu SLB Putra Mandiri Tarik, dan SMALB Putra Mandiri Lebo Sidoarjo. Jaringan kerja lintas sektor yang telah terbangun dalam penerapan strategi transformasi pengalaman diri sangat membantu kepala sekolah utamanya dalam menjalin 
kerjasama dengan perusahaan untuk penyaluran lulusan sehingga permasalahan yang dihadapi sekolah binaan cepat terpecahkan.

Peran jaringan kerja lintas sektor juga menjadi salah satu trigger lancarnya pelaksanan strategi untuk meningkatkan kompetensi kepala sekolah, faktor yang lainnya adalah: (1) banyaknya lulusan yang belum tertangani, (2) desakan orang tua siswa agar sekolah membantu mencari jalan keluar untuk mengatasi kebuntuan akses lulusan dalam memasuki kedunia kerja, (3) cukup kuatnya keinginan kepala sekolah, dan guru agar peserta didiknya berhasil, (4) adanya Undang-Undang nomer 8 tahun 2016 tentang Penyandang Disabilitas, pasal 53 ayat 2 yang menyatakan bahwa, perusahaan swasta wajib mempekerjakan paling sedikit $1 \%$ (satu ) penyandang disabilitas dari jumlah pegawai/pekerjanya.

Langkah-langkah penerapan strategi transformasi pengalaman diri adalah sebagai berikut:

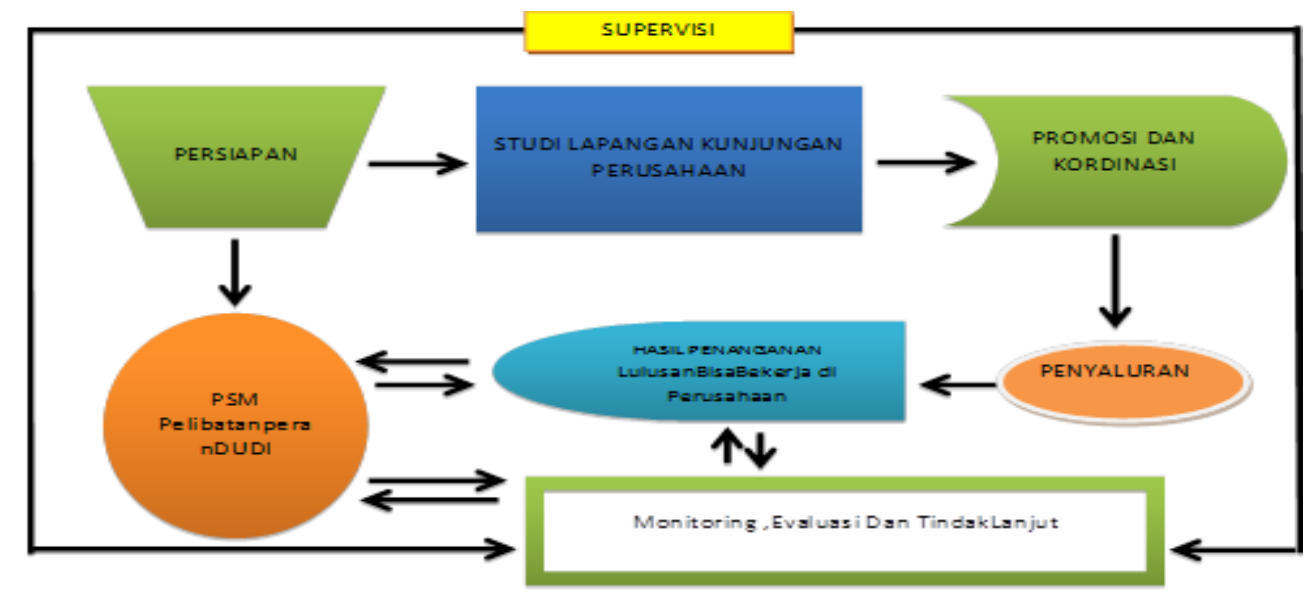

Gambar 2.1. Langkah-langkah Strategi

\section{Persiapan}

Berbagai hal yang terkait dengan program pembinaan, yang perlu dilakukan adalah persiapan. Persiapan dilakukan dengan mengumpulkan kepala sekolah binaan untuk evaluasi diri capaian visi, misi dan tujuan di sekolah masing-masing. Pada pertemuan berikutnya sekolah diminta membuat data penelusuran lulusan untuk mengetahui kondisinya. Pada tahap persiapan penulis mendampingi kepala sekolah menyusun program, dan membentuk tim beserta penanggung jawabnya. 


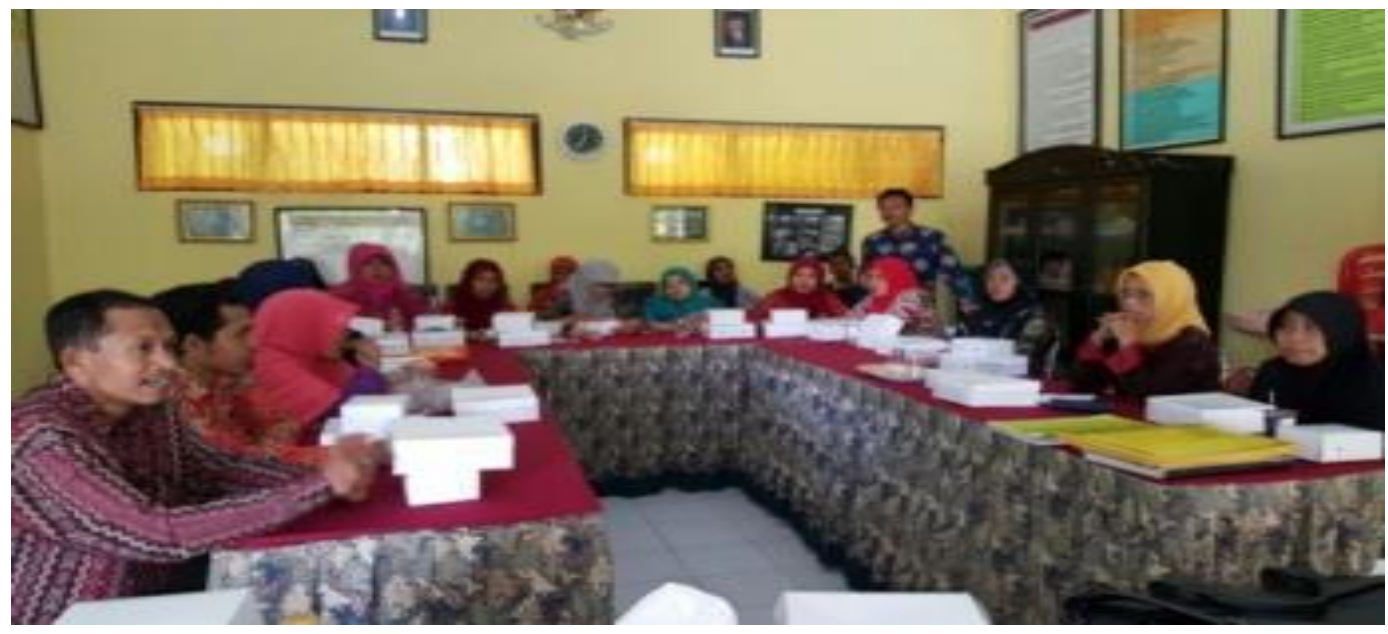

Gambar 2.2. Persiapan bimbingan

\section{Studi Lapangan Kunjungan ke Perusahaan}

Studi lapangan dilakukan dengan memfasilitasi, dan mendampingi kepala sekolah dan guru ketrampilan mengunjungi PT. First Medipharma Candi, PT. UFI di Wonoayu dan PT. Young Tree di Tulangan. Kunjungan lapangan memberikan kesempatan untuk mengetahui berbagai hal, termasuk bepeluang apa yang akan bisa dimanfaatkan sekolah, maupun lulusan. Melalui kunjungan keperusahaan kepala sekolah, dan guru memperoleh pengalaman, dan umpan balik yang sangat berharga untuk memperbaiki program pendidikan.

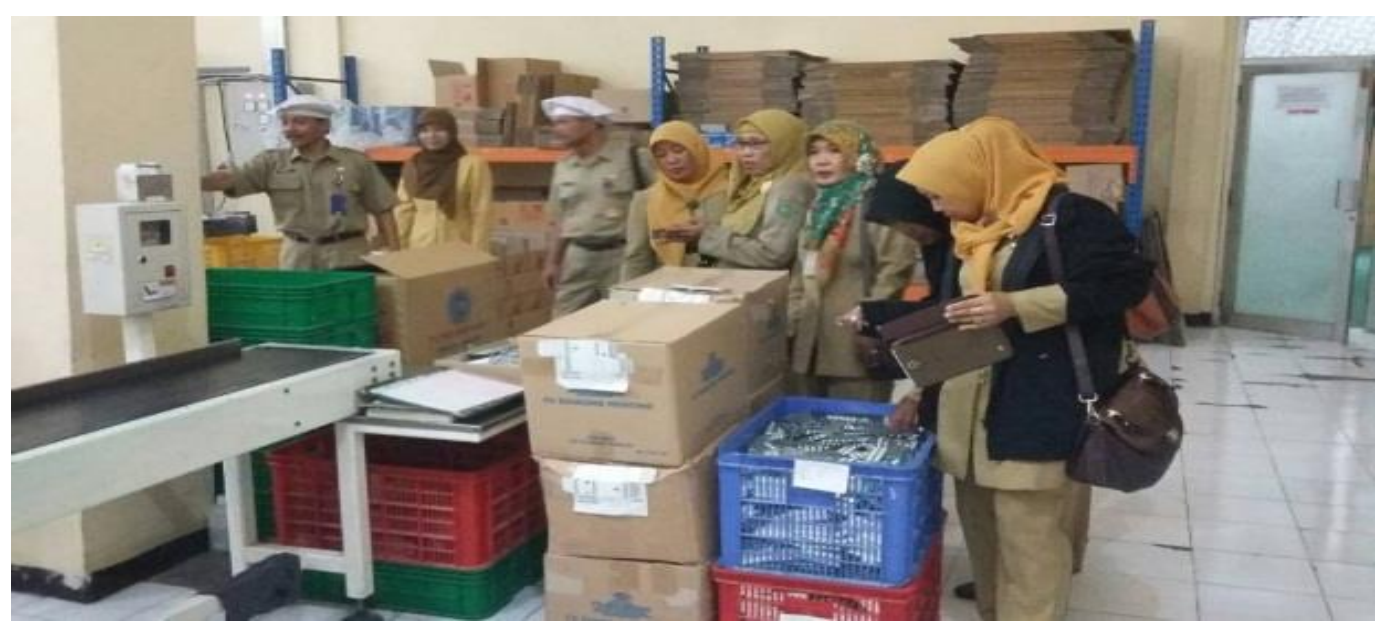

Gambar 2.3. Studi lapangan ke PT. First Medipharma 


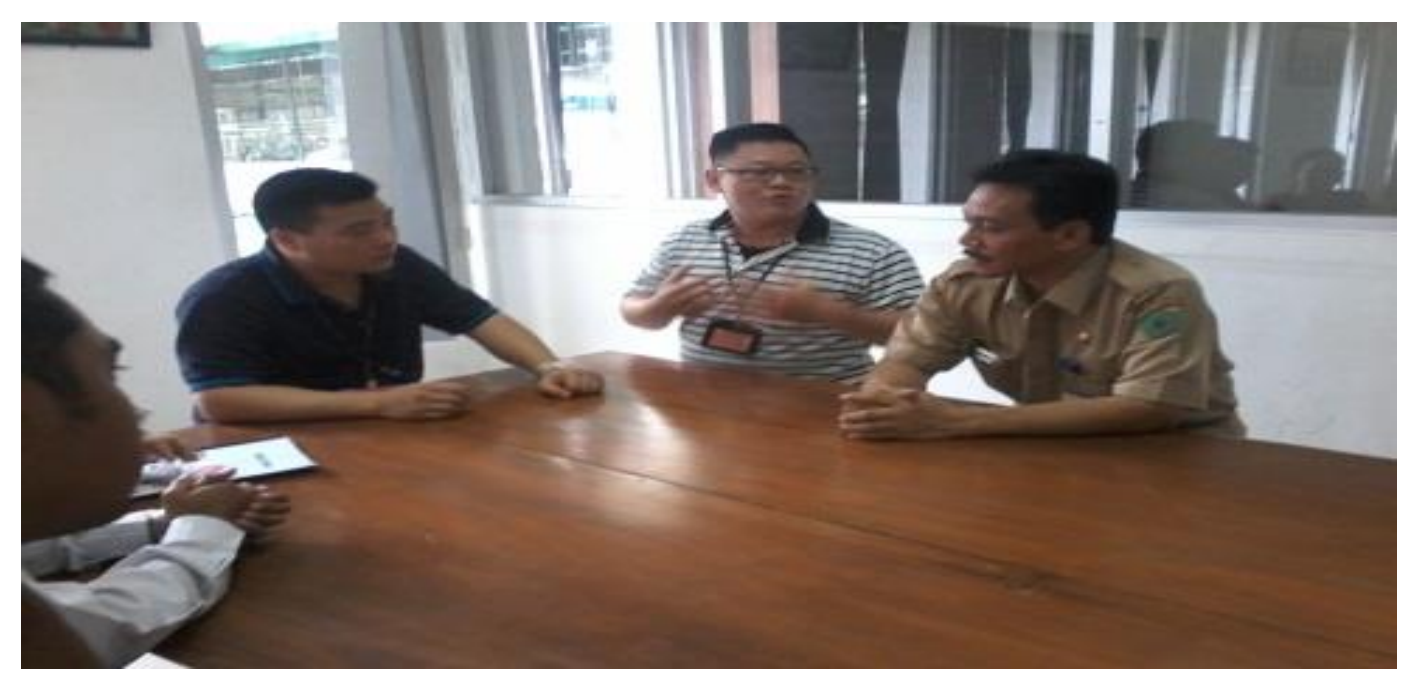

Gambar 2.4. Menemui General Manager PT. Young Tree (Mr. Lee)

Tujuan dari kunjungan ini antara lain:

a. Menjalin hubungan untuk menumbuhkan simpati dan empati terhadap hambatan dan kesulitan yang dialami peserta didik berkebutuhan khusus.

b. Membangun relasi, dan kemitraan, oleh karena sumber daya yang dimiliki pihak sekolah terbatas, peran dunia usaha sangat diperlukan untuk membantu terselenggaranya pendidikan yang relevan dengan kebutuhan dunia kerja khususnya melatih ketrampilan dan menyerap lulusannya.

c. Agar kepala sekolah dan guru pendamping memperoleh pengalaman, saran dan masukkan secara langsung dari pihak perusahaan.

d. Pihak perusahaan mendapat kepastian keuntungan atau manfaat apa yang diperoleh dari memperkerjakan lulusan, setelah mendapatkan masukan dari pihak kepala sekolah dan dinas, serta instansi terkait.

Banyaknya masukkan yang diperoleh kepala sekolah dalam studi lapangan dapat memperkaya data, dan informasi tentang kebutuhan lulusan terkait dengan jenis, tingkat kesulitan dan peluang kerja yang tepat bagi lulusannya. Pada saat studi lapangan ini penulis memperkenalkan kepala sekolah beserta jajarannya dengan manajer personalia, staf maupun karyawan perusahaan, untuk melakukan berdiskusi berbagai hal yang terkait dengan perusahaan. Dalam diskusi ini delegasi yang diajak penulis juga dapat mengamati berbagai peralatan, proses produksi, jenis-jenis ketrampilan dasar yang perlu dilatihkan pada siswa di sekolah masing-masing. 
Pengalaman dari kunjungan diperusahaan ini tentu sangat berharga bagi kepala sekolah beserta jajarannya, sehingga memungkinkan mereka dapat merancang kurikulum atau program pembelajaran yang sesuai dengan kebutuhan perusahaan. Dalam kesempatan kunjungan diperusahaan itu penulis juga memfasilitasi kepala sekolah untuk berkonsultasi dengan pihak perusahaan. Mengajukan permohonan ijin untuk memagangkan peserta didik kelas XI untuk membekali sikap mental dan ketrampilan sesuai kebutuhan perusahaan.

\section{Promosi dan Koordinasi}

Promosi merupakan langkah penting untuk membangun jaringan kerjasama lintas sektor. Teknik promosi menggunakan model 5M, yaitu mengenali pelanggan dengan baik, memperkenalkan diri atau produk milik kita, memanfaatkan setiap peluang, dan dalam waktu lima detik ketemu orang dalam jarak satu meter penulis mengajak guru dan kepala sekolah melakukan promosi, promosi dan terus berpromosi. Dalam langkah promosi ini penulis meyakinkan pada guru dan kepala sekolah agar berperan sebagai penyambung lidah, agar diri kita bisa memberi manfaat sebesar-besarnya bagi orang lain. Promosi penting dilakukan untuk memperkenalkan potensi secara obyektif kepada para pihak yang berkepentingan. Harapannya agar pihak satu dengan lainnya bisa menerima dan ikut membantu anak berkebutuhan khusus dalam segala aspek kehidupan dan penghidupannya. Peserta didik yang lulus diupayakan bisa kembali ke masyarakat dengan citra diri yang baik.

Koordinasi dilakukan untuk membangun jaringan kerja dengan lintas sektor. Koordinasi dalam penyaluran lulusan misalnya, kepala sekolah dan jajarannya harus melibatkan orang tua/wali siswa dalam mensosialisasikan program penyaluran. Pentingnya pelibatan orang tua siswa agar dalam proses pembekalan, dapat memberikan motivasi sehingga anak tumbuh kepercayaan dirinya dalam proses seleksi sampai pada tahap training agar berhasil bekerja di perusahaan.

Langkah koordinasi meliputi, membimbing kepala sekolah, dan guru praktek bernegosiasi, berkolaborasi, dan memberi jaminan terhadap lulusan yang akan disalurkan kepada pihak perusahaan. Langkah promosi dan koordinasi sangat menentukan terutama dalam hal memberikan jaminan bahwa lulusan yang disalurkan tidak akan mengecewakan atau merugikan perusahaan.

\section{Penyaluran Lulusan di Perusahaan}

Penyaluran merupakan kesempatan yang sangat di tunggu oleh para lulusan dan sangat diharapkan oleh orang tua setelah anaknya lulus dari jenjang SMALB. Upaya penyaluran lulusan merupakan langkah yang sangat mungkin bisa dilakukan dan harus 
dilakukan tetapi dalam prakteknya belum banyak yang berhasil melakukan. Fakta di lapangan dalam beberapa tahun terakhir ketika penulis memposting informasi ke media sosial melalui whatsApp atau sms respon yang masuk dari lulusan cepat dan banyak. Jika perusahaan menawarkan lima formasi maka yang mengajukan surat lamaran mencapai 15-20 lulusan. Kondisi ini mempertegas bahwa program penyaluran benar-benar dibutuhkan oleh lulusan sebagaimana, SMK maupun Perguruan Tingi yang memfasilitasi program job market fair bagi lulusannya.

Program penanganan lulusan di sekolah binaan di tangani oleh tim yang terdiri dari guru pendamping dan orang tua siswa. Dalam proses penyaluran guru dan orang tua bekerjasama mempersiapkan kelengkapan dokumen administrasi, mengantar tes kesehatan ke laboratorium yang ditunjuk, wawancara di perusahaan, serta pembekalan kepada lulusan. Berikutnya menjelaskan tentang tugas, tanggung jawab, dan hak-hak karyawan, mendoakan dan membantu agar anaknya berhasil dalam bekerja di perusahaan. Proses yang dilalui pun secara bertahap. Peran orang tua selanjutnya mengantar dan mendampingi lulusan yang diterima, mengikuti orientasi / training di perusahaan. Selesai training kepala sekolah dan jajarannya menitipkan lulusan kepada kepala bagian, dan karyawan dalam satu departemen, dan petugas security agar ikut membantu.
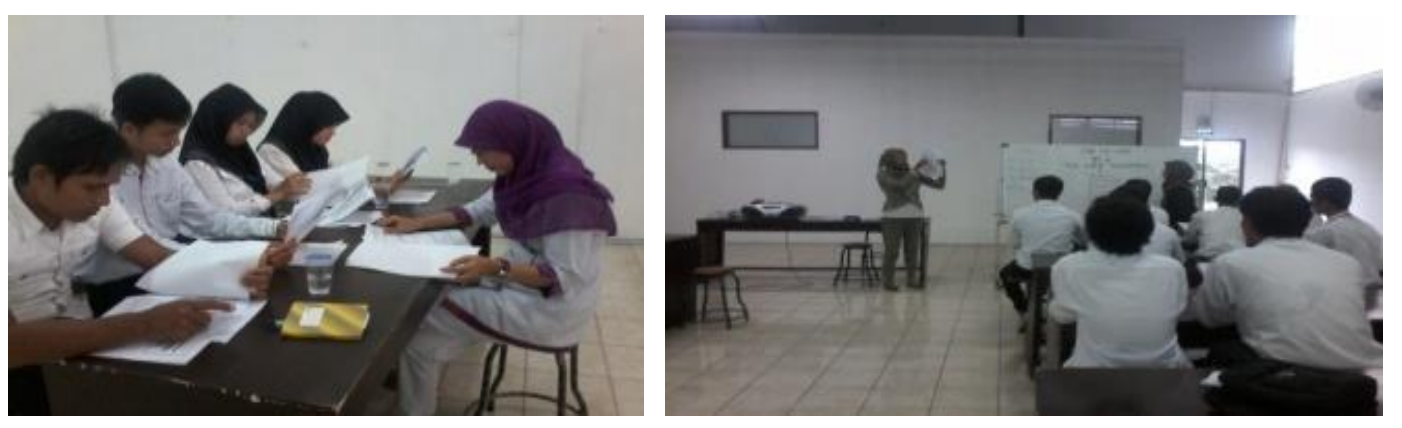

Gambar 2.5. Pendampingan tes wawancara dan masa training

\section{Monitoring Evaluasi dan Tindak Lanjut}

Monitoring, evaluasi, dan tindak lanjut dilakukan bersama kepala sekolah atau guru pendamping untuk meyakinkan bahwa program penyaluran lulusan sangat bermanfaat, dan layak diteruskan. Lulusan yang gagal dibina lebih lanjut bekerjasama dengan orang tuanya, jika memungkinkan disalurkan pada kesempatan lain di perusahaaan yang berbeda. 
Untuk meyakinkan pihak perusahaan bahwa kerjasama penyaluran lulusan dari SMALB sebagai tenaga kerja penyandang disabilitas, memiliki dasar yang kuat, penulis bekerjasama dengan Dinas Tenaga Kerja Kabupaten Sidoarjo, dan Propinsi Jawa Timur, serta, Kemenaker maupun Kemendikbud untuk memberikan penghargaan.

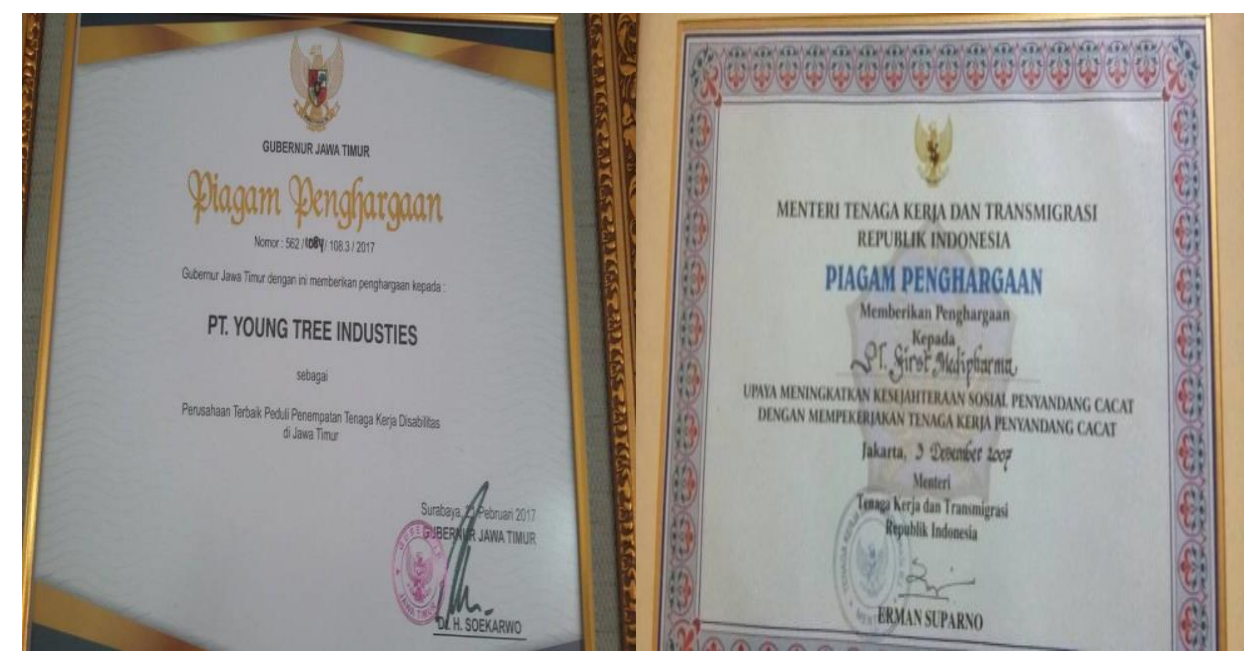

\section{Gambar 2.6. Penghargaan perusahaan yang peduli terhadap penyandang disabilitas.}

Hal ini sesuai Undang-Undang nomer 8 tahun 2016 tentang penyandang disabilitas. PT. Young Tree dan PT. UFI telah mendapatkan penghargaan dari Gubernur Jawa Timur dan bulan Desember nanti PT. First Medipharma diajukan agar mendapat penghargaan dari Presiden sebagai perusahaan yang peduli terhadap penyandang disabilitas,.

\section{A. Waktu, Tempat, dan Biaya}

\section{Waktu pelaksanaan}

Penulis melaksanaan pembinaan dalam beberapa fase yaitu :

a. Fase pertama mulai bulan Agustus sampai Oktober 2014 persiapan, penyusunan program, dan pembentukan tim penanganan serta fasilitasi studi lapangan

b. Fase kedua mulai bulan Nopember sampai Desember 2014 fasilitasi kerjasama dengan perusahaan dan dinas/ instansi terkait.

c. Fase ke tiga mulai bulan Januari sampai Maret 2015 pendampingan awal penyaluran ke perusahaan, kordinasi dan pembinaan.

d. Fase ke empat mulai bulan April sampai Desember 2015 penyaluran lanjutan, monitoring, evaluasi dan tindak lanjut.

e. Fase ke lima bulan Januari 2016 sampai sekarang, penandatangan MoU, kordinasi, pembinaan dan penyaluran lanjutan. 


\section{Tempat pelaksanaan}

Tempat pelaksanaan pembinaan di sekolah luar biasa binaan di Kabupaten Sidoarjo secara bergilir sesuai jadwal pelaksanaan pengawasan. Tempat koordinasi di SMALB Putra Mandiri Lebo dengan pertimbangan lokasi yang mudah dijangkau.

\section{B. Biaya}

Biaya pelaksanaan kegiatan ini dibebankan pada masing-masing pihak secara secara rmandiri, dan sebagian besar ditanggung penulis.

\section{Hasil, dan Dampak}

\section{Hasil}

a. Pembinaan, membawa perubahan pada pola pengelolaan sekolah, yaitu kepala sekolah mampu mendayagunakan peran serta masyarakat dalam jaringan kerja lintas sektor, sehingga kualitas pengelolaan intput, dan proses pembelajaran lebih baik.

b. Kepala sekolah memiliki program, dan tim penganganan dalam kurun waktu 3 tahun $71 \%$ lulusan dapat disalurkan di empat perusahaan, sehingga outcame-nya mampu mandiri dimasyarakat.

c. Penerapan pola ini telah mengantarkan Ibu Endang Sulistyorini berhasil menjadikan kepala sekolah berprestasi tahun 2016.

d. Ibu Dwi Wahyuni sebagai kepala sekolah SMALB Putra Mandiri, mampu berperan sebagai coordinator, dan berhasil membuat MoU, dengan tiga perusahaan, sehingga terbangun akses yang memudahkan lulusnnya memperoleh pekerjaan.

e. Dua sekolah binaan yaitu, SLB - AC, dan SLB - B Dharma Wanita Sidoarjo dalam akreditasi sekolah mendapatkan predikat A.

f. Kepala sekolah responsif dalam menindak lanjuti informasi, dan peluang dengan jiwa kewirausahaannya peserta didik lulusan tahun 2017 yang memenuhi syarat telah dapat disalurkan di empat perusahaan sebelum menerima ijazah.

g. Terbangunnya akses yang memudahkan lulusan dari sekolah binaan, maupun dari luar binaan dari Propinsi Jawa Timur, Jogya, maupun Jawa Tengah, memperoleh pekerjaan di perusahaan.

h. Perusahaan mitra merasa tersanjung memperoleh penghargaan dari, Pemerintah Kabupaten, Provinsi,maupun Pemrintah pusat sehingga lebih semangat dan peduli terhadap penanganan lulusan. 


\section{Dampak}

Dampak internal yaitu:

a. Reputasi dan citra sekolah meningkat, dua sekolah binaan yaitu SMALB-AC, dan SMALB-B Dharma Wanita Sidoarjo dalam akreditasi mendapat berpredikat A

b. Warga sekolah senang dan bangga peserta didiknya berhasil

c. Lulusan atau alumni dapat memotivasi adik kelasnya agar lebih giat belajar dan berkarya.

d. Kepala sekolah binaan semangat merintis usaha-usaha kecil yang dikaitkan dengan program ketrampilan untuk melatih jiwa dan budaya kewirausahaan warga sekolah di sekolah masing-masing

Dampak eksternalnya yaitu:

a. Orang tua bangga anaknya bisa diterima bekerja diperusahaan berpenghasilan layak dan mampu mandiri.

b. Dunia usaha percaya kemampuan lulusan dari SLB.

c. Masyarakat mengenal dan mengapresiasi kemampuan lulusan dengan lebih obyektif, sehingga stigma terhadap anak berkebutuhan khusus, berubah kearah yang positif.

d. PT.First Medipharma dan PT.UFI menyalurkan dana CSRnya untuk membantu SMALB Putra Mandiri dalam mengembangkan sekolahnya.

\section{SIMPULAN DAN SARAN}

\section{A. Simpulan}

a. Pembinaan kompetensi kewirausahaan kepala sekolah melalui transformasi pengalaman diri dapat dilakukan melalui langkah-langkah, persiapan, study lapangan, promosi, dan koordinasi, serta penyaluran lulusan, monitoring, evaluasi dan tindak lanjut.

b. Hasilnya cukup signikan yaitu: (1) kepala sekolah binaan mampu menyusun program dan tim penanganan lulusan, (2) menghasilkan memorandum of understanding ( MoU) menjadi akses yang memudahkan lulusan memperoleh pekerjaan, (3) visi sekolah mewujudkan lulusan yang mandiri bisa dicapai, (4) dalam waktu 3 tahun $71 \%$ lulusan dapat disalurkan di empat perusahaan.

c. Dampaknya citra sekolah menjadi baik, guru, dan orang tua bangga lulusannya mampu bekerja, dan memiliki penghasilan yang layak, serta mandiri. .

\section{B. Saran}

Berdasarkan simpulan tersebut diatas penulis memberikan saran sebagai berikut: 
a. Kepada kepala sekolah binaan, terus meningkatkan kompetensinya untuk memperbaiki kualitas pengelolaan input, proses, output, dan outcomenya pada tahun pelajaran berikutnya.

b. Kepada pengawas lain dapat menerapkan strategi ini untuk membantu kepala sekolah binaan dalam mengatasi permasalahan yang sama.

\section{Harapan Masa Depan}

a. Kepala sekolah terus memperbaiki pelayanan pendidikan dan memperluas jaringan kerja lintas sektor untuk meningkatkan mutu lulusan sesuai kebutuhan masyarakat penggunanya.

b. Memperluas, dan memperkuat jaringan kerjasama lintas sektor, yang sudah terbukti mampu berperan sebagai penopang terselenggaranya pelayanan pendidikan khusus, menuju tercapainya tujuan pendidikan.

\section{DAFTAR PUSTAKA}

Amti, Erman dan Prayitno. 2004. Layanan bimbingan dan konseling kelompok. Padang: Jurusan Bimbingan dan Konseling Fakultas Ilmu Pendidikan Universitas Negeri Padang.

Depdikbud. 1998. Panduan Manajemen Sekolah. Balai Pustaka, Jakarta

Depdiknas.2000. Panduan Manajemen Sekolah. Direktorat Jenderal Pendidikan Dasar dan Menengah. Direktorat Pendidikan Menengah, Jakarta.

Kemdikbud 2013, Materi Bimtek Peningkatan manajemen Kepala Sekolah PK.Dirjen Pendidikan Menengah, Jakarta.

Kemdikbud 2015, Pusat Pengembangan Tenaga Kependidikan Kemdikbud (Buku Kerja Pengawas Sekolah), Jakarta.

Kemdikbud 2011, Pusat Pengembangan Tenaga Kependidikan Kemdikbud, Jakarta 2011, Buku Kerja Pengawas Sekolah, Jakarta.

Undang-Undang Nomor 20 Tahun 2003.Sistem Pendidikan Nasional. Media Wacana, Yogyakarta.

Undang Undang Nomor 8 Tahun 2016 Tentang Penyandang Disabilitas

Widjaja, A.W, 1998, Titik Berat Otonomi Daerah : Pada Daerah Tingkat II, PT. Raja Grafindo, Jakarta 


\section{LAMPIRAN FOTO KEGIATAN}

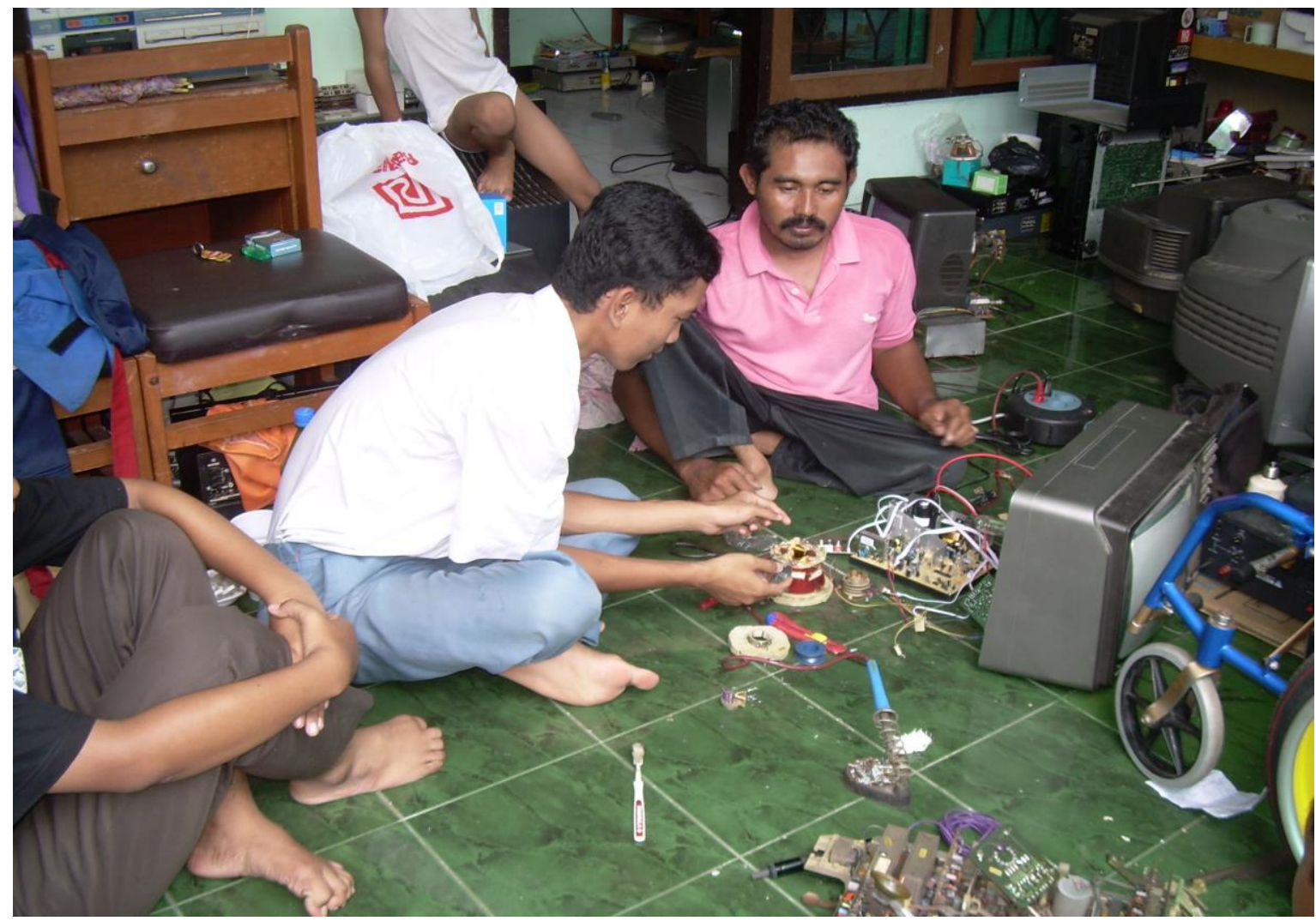

Pembekalan sikap mental dan etos kerja melalui magang di bengkel elektro Pak Hari

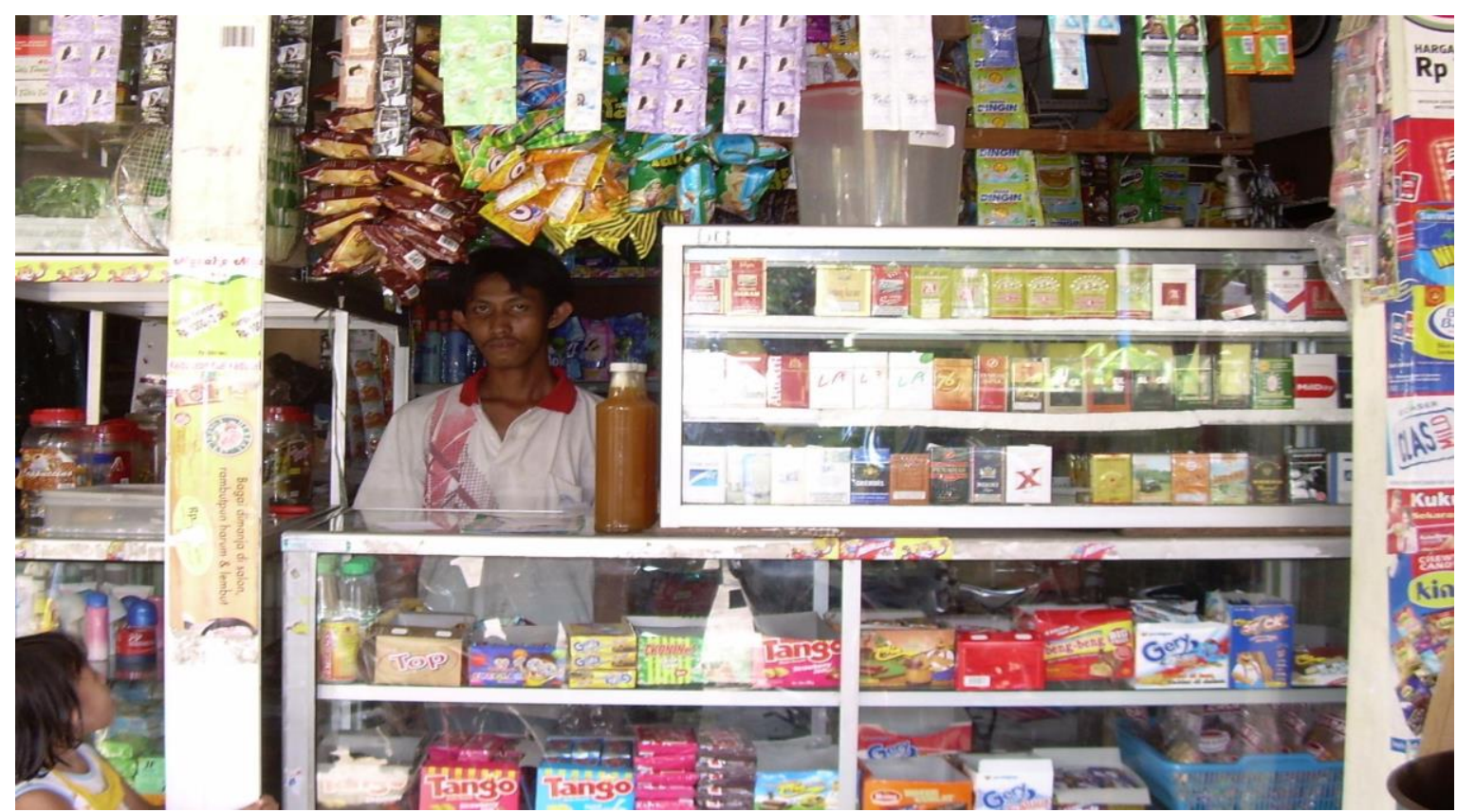

Pembekalan melalui magang kerja di toko kelontong 

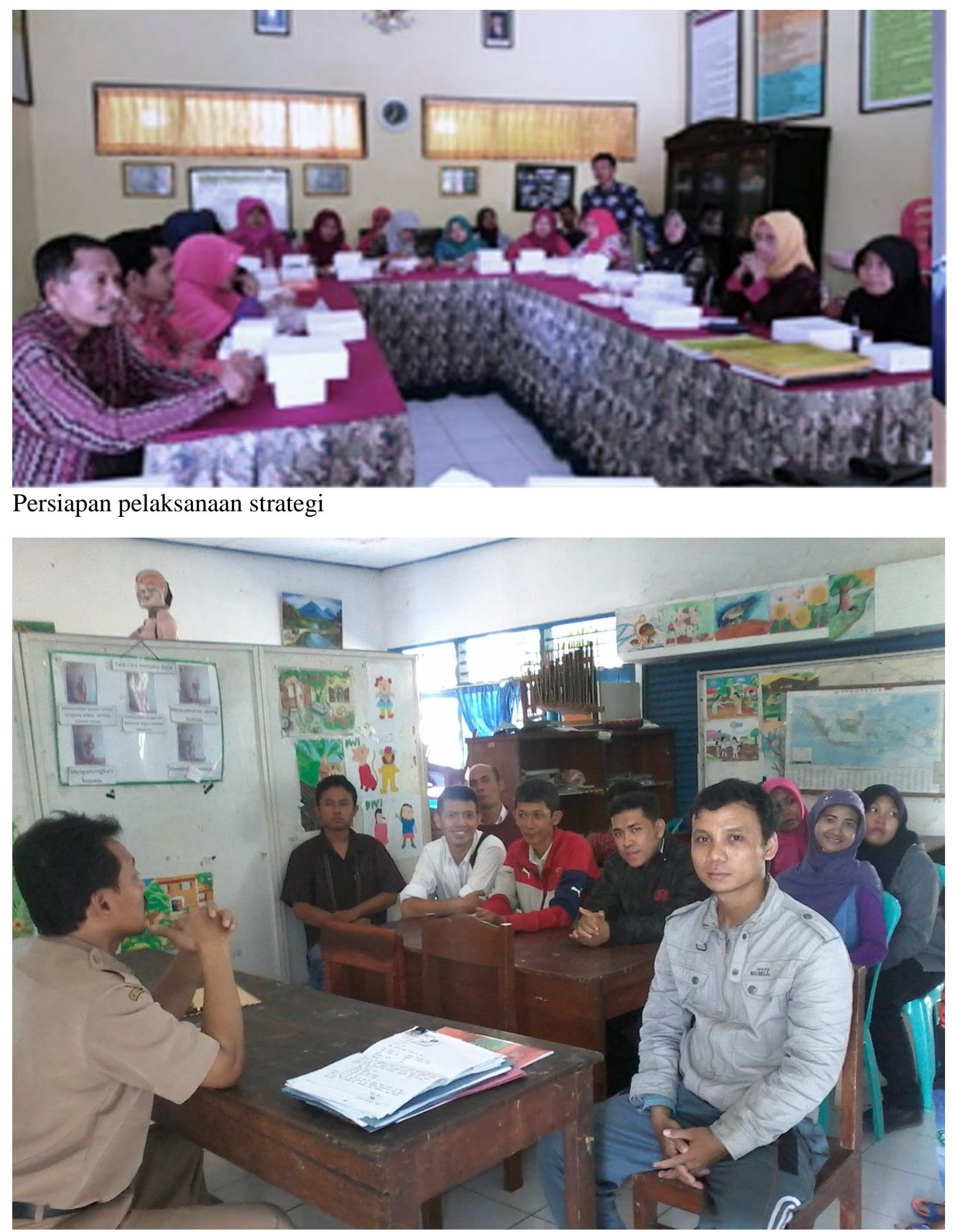

Pembekalan kepada peserta didik yang akan disalurkan 


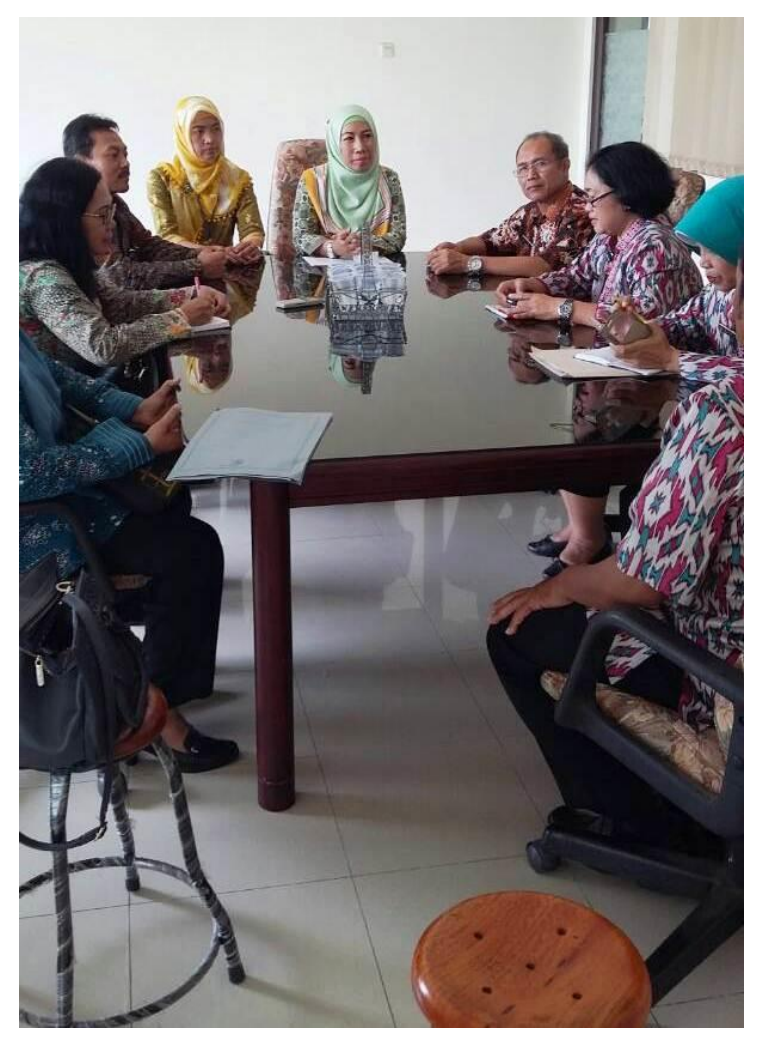

Koordinasi lintas sektor

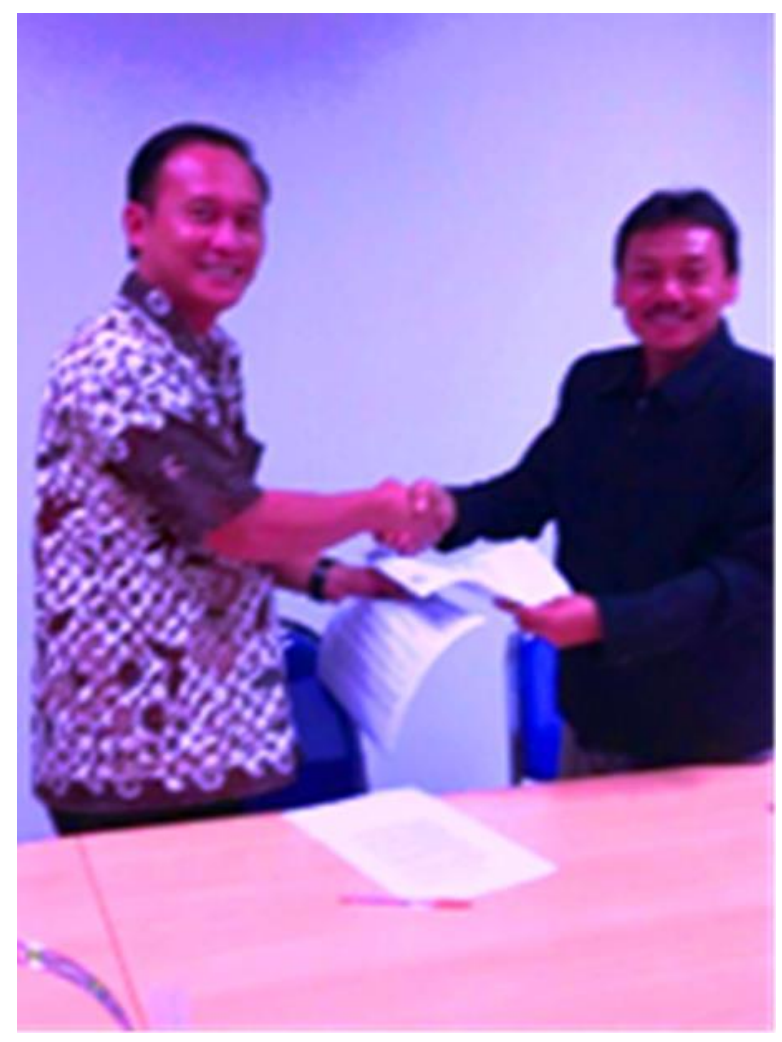

Koordinasi permintaan karyawan baru

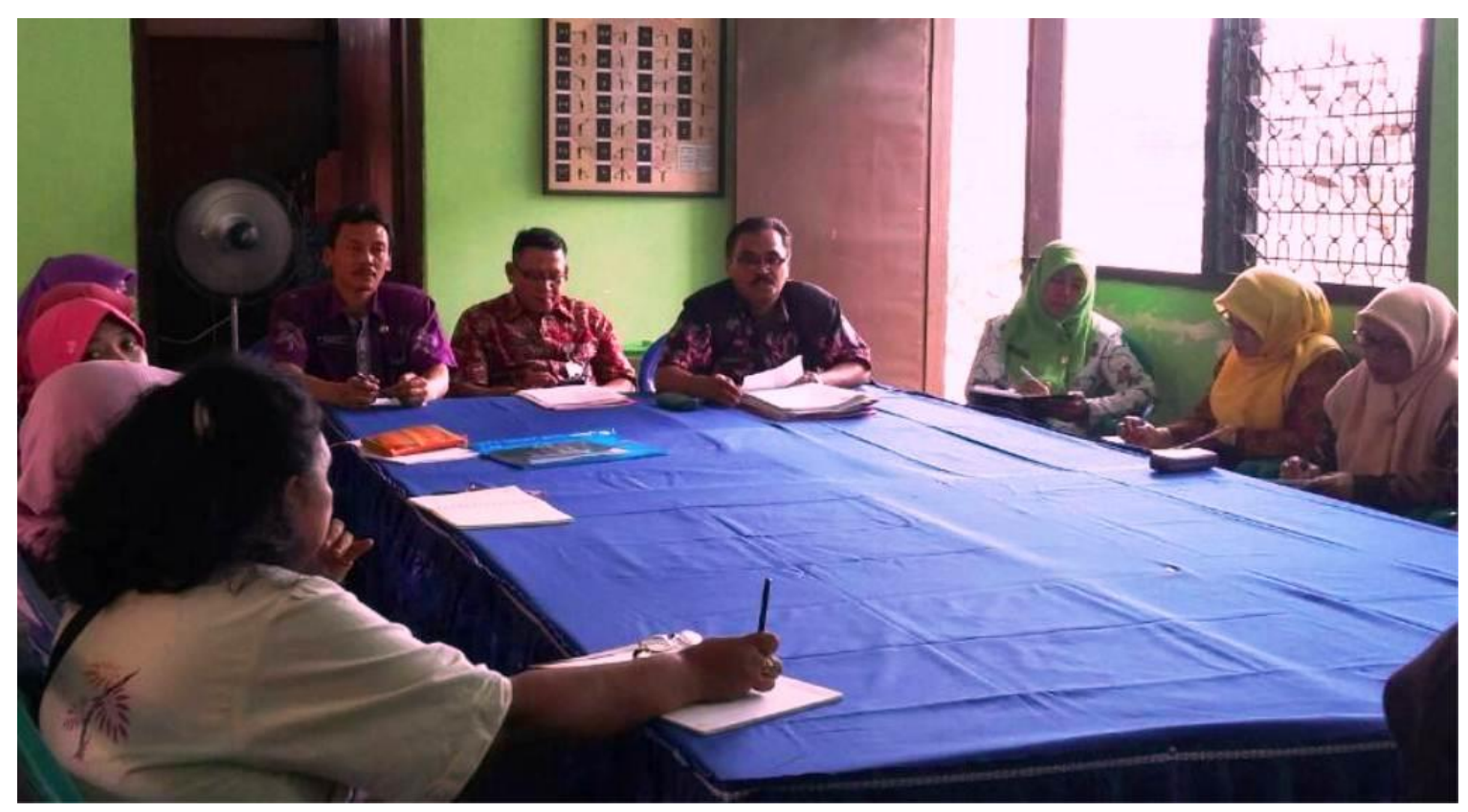

Koordinasi persiapan pembinaan 


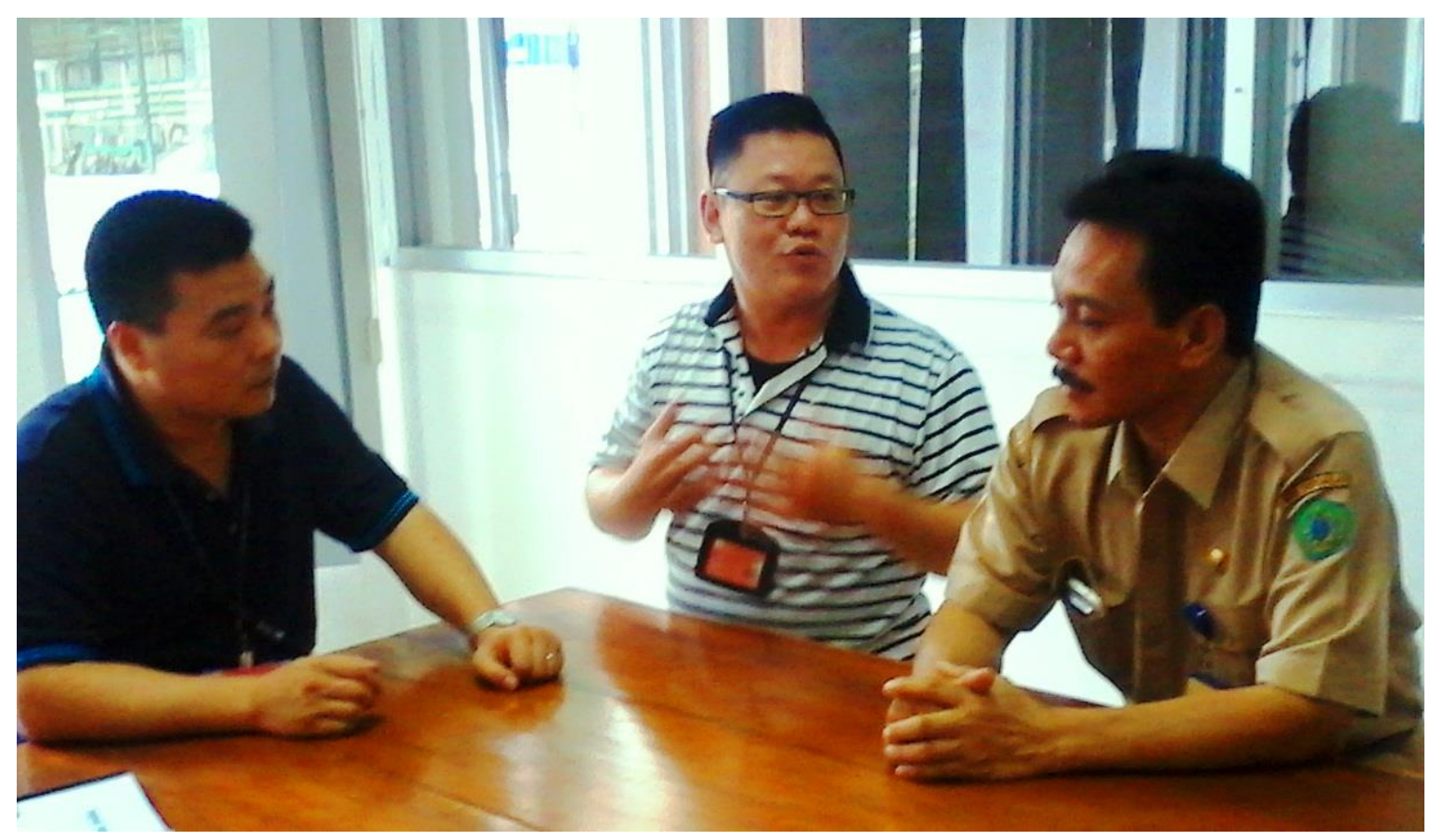

Menemui General Manager di PT. Young Tree

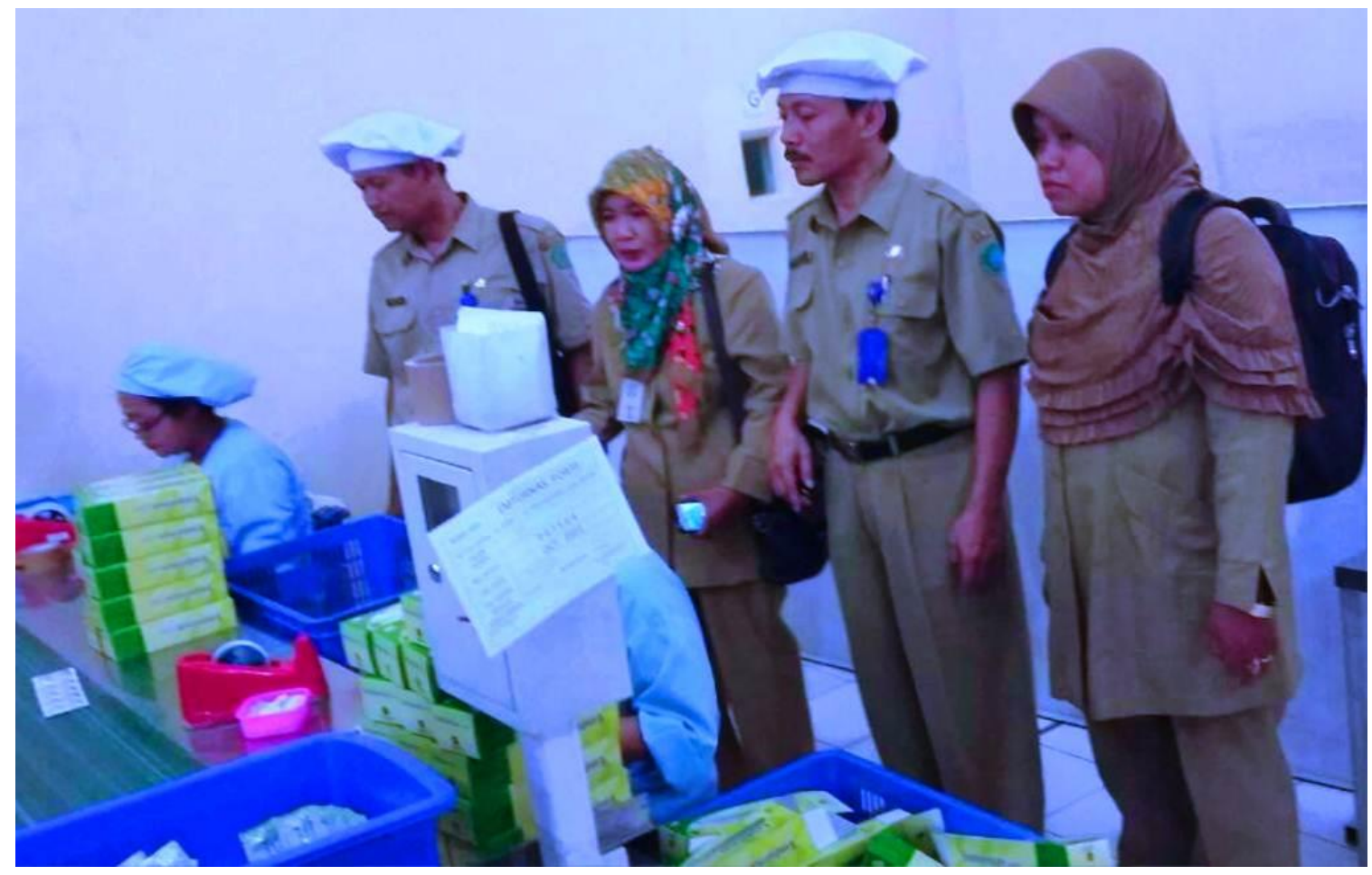

Filitasi, dan pendampingan kepala sekolah / guru dalam kunjungan di PT Fisrt Medipharma 


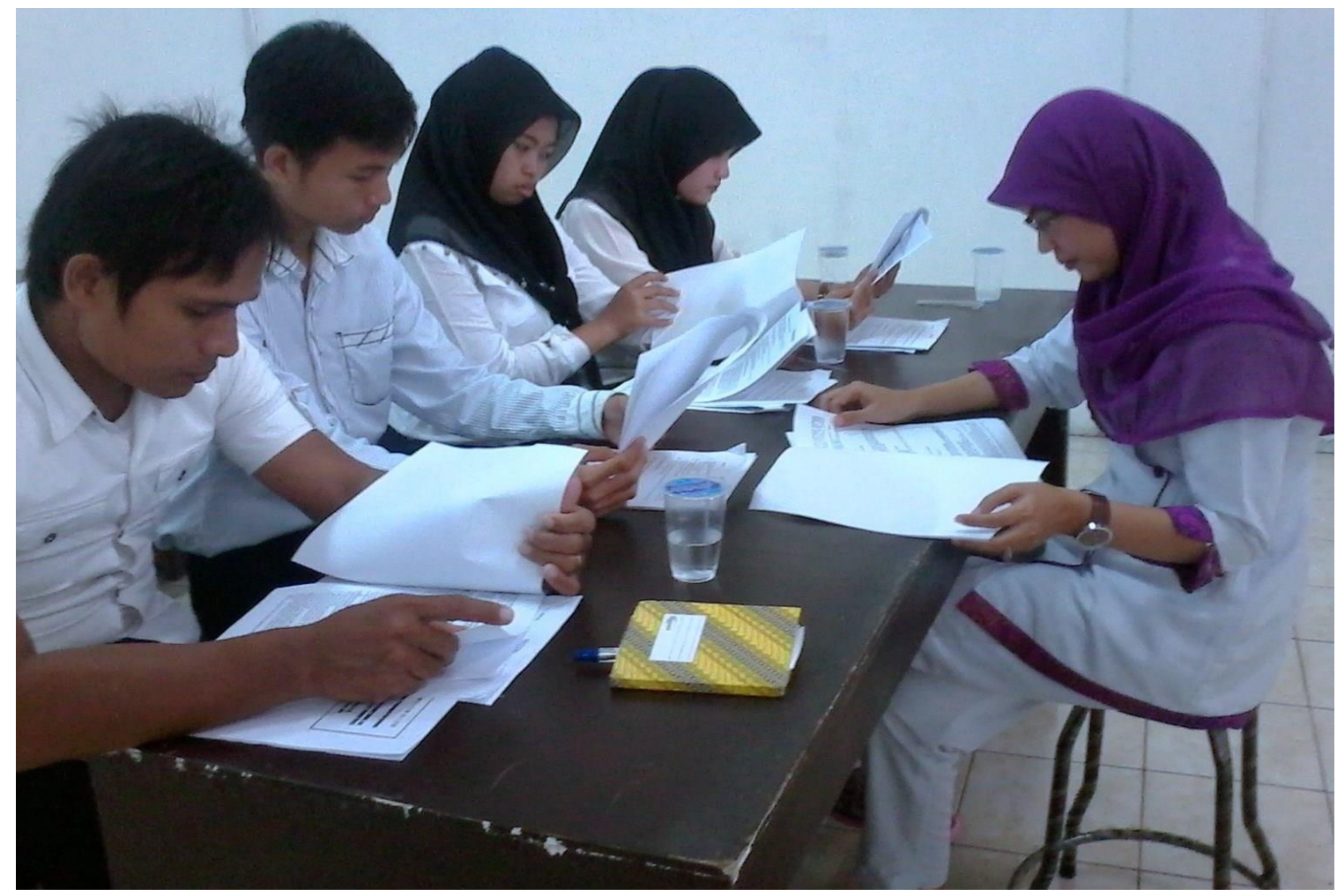

Pendampingan training di PT. Young Tree

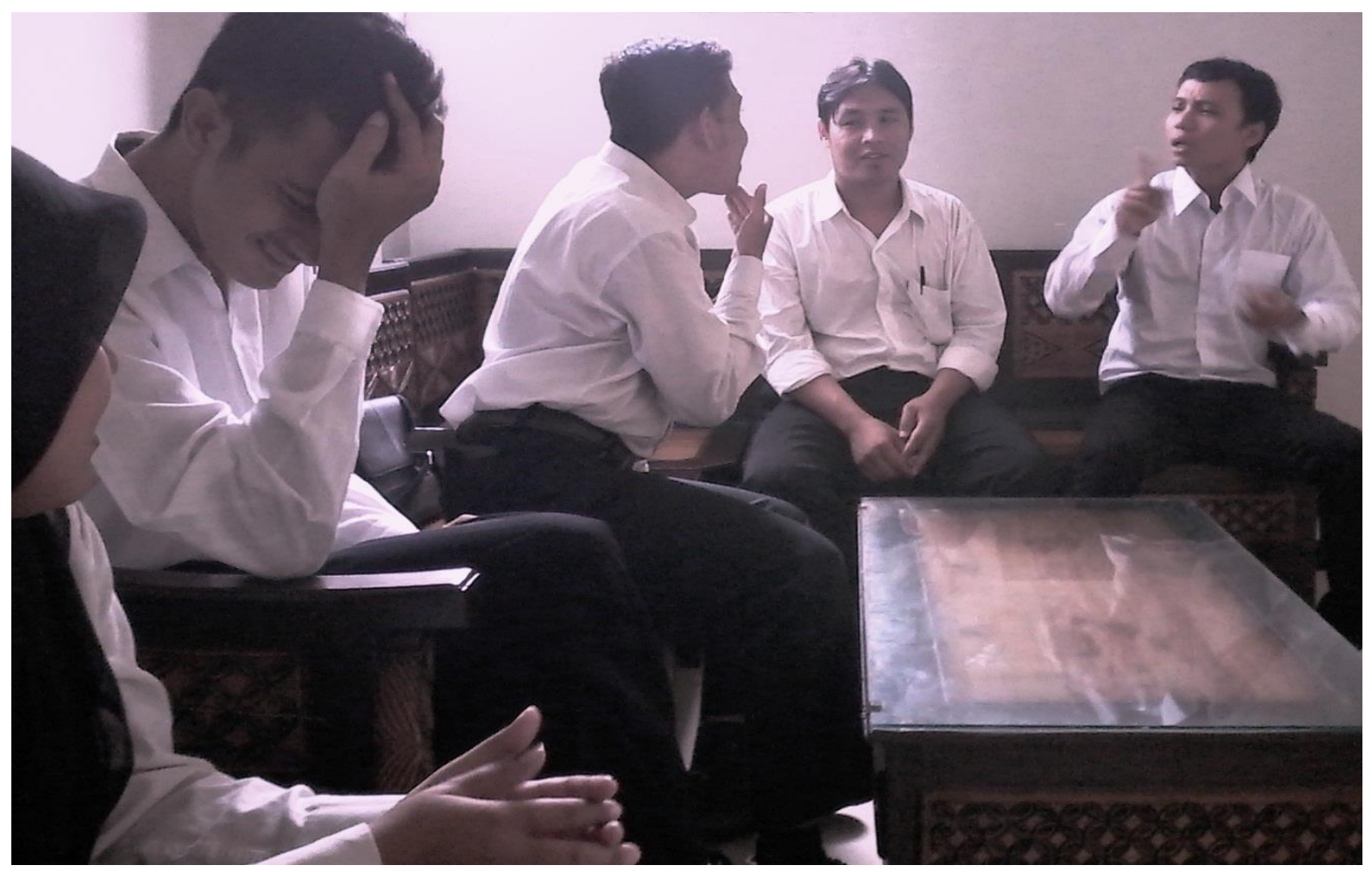

Mendampingi lulusan test wawancara di perusahaan 


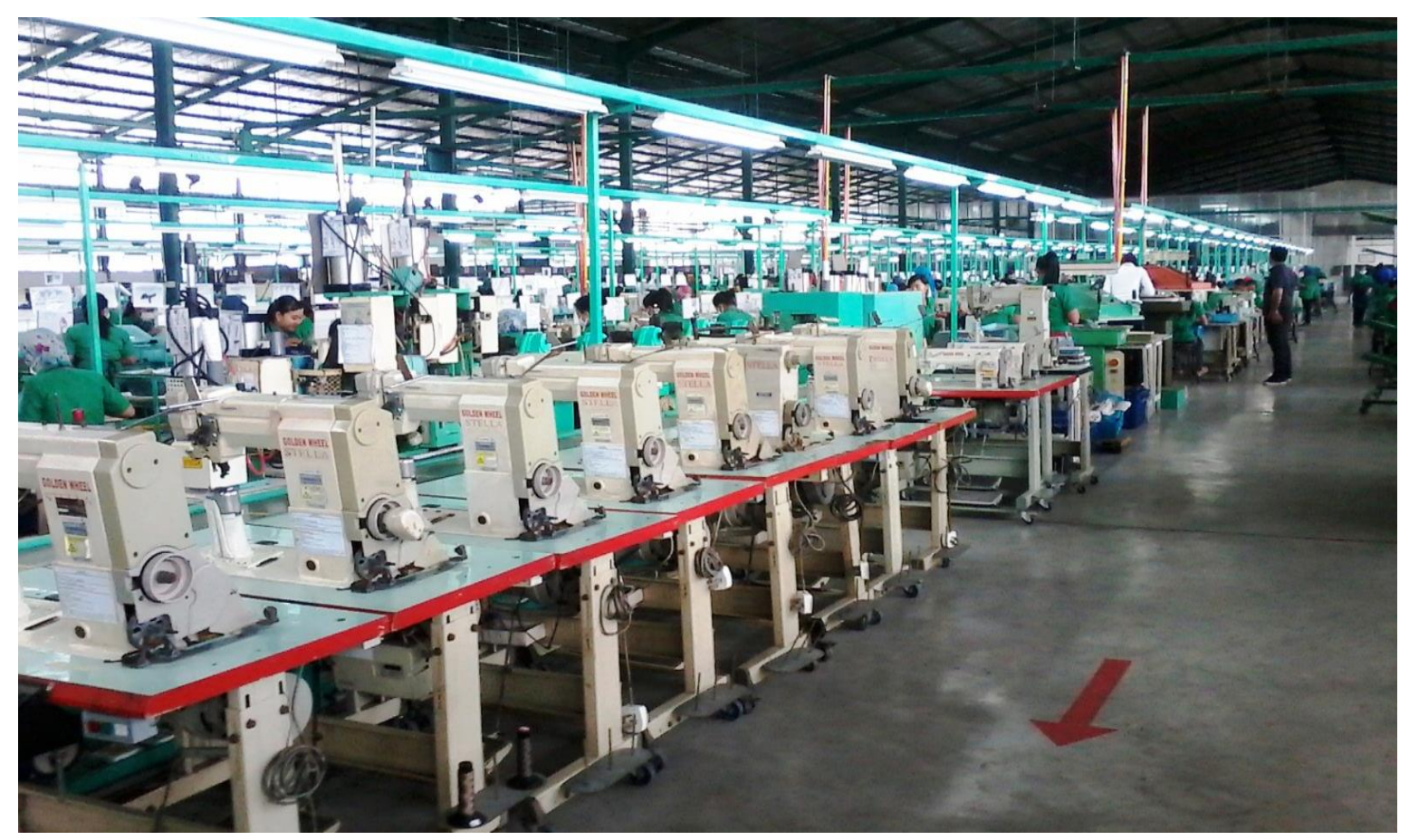

Suasana PT Young Tree

Tabel hasil pembinaan

\begin{tabular}{|c|l|l|l|l}
\hline No & \multicolumn{1}{|c|}{ Nama Sekolah } & \multicolumn{1}{|c|}{ Program } & Penanggung Jawab & Keterangan \\
\hline 1 & SLB Putra Mandiri & $\begin{array}{l}\text { Pengembangan diri } \\
\text { dan kemandirian }\end{array}$ & Dwi Wahyuni, S.Pd & $\begin{array}{l}\text { Kepala } \\
\text { sekolah }\end{array}$ \\
\hline 2 & SLB-B Dharma Wanita & $\begin{array}{l}\text { Penyiapan dan } \\
\text { Penanganan Siswa }\end{array}$ & $\begin{array}{l}\text { Endang S.Pd } \\
\text { Sulistyorini, }\end{array}$ & $\begin{array}{l}\text { Kepala } \\
\text { Sekolah }\end{array}$ \\
\hline 3 & SLB Veteran Wonoayu & $\begin{array}{l}\text { Pengembangan diri } \\
\text { dan Kemandirian }\end{array}$ & Sulistiyani,S.Pd & $\begin{array}{l}\text { Kepala } \\
\text { Sekolah }\end{array}$ \\
\hline 4 & $\begin{array}{l}\text { SLB Al Qusnaeni } \\
\text { Sukodono }\end{array}$ & $\begin{array}{l}\text { Penyiapan dan } \\
\text { Penanganan Lulusan }\end{array}$ & Sutiasih & $\begin{array}{l}\text { Kepala } \\
\text { Sekolah }\end{array}$ \\
\hline 6 & SLB Aisyiah Tulangan & $\begin{array}{l}\text { Pengembangan diri } \\
\text { dan Kemandirian }\end{array}$ & Siti Juliarti,S.Pd & $\begin{array}{l}\text { Kepala } \\
\text { Sekolah }\end{array}$ \\
\hline
\end{tabular}


Pembinaan Kompetensi Kewirausahaan Kepala Sekolah Melalui Transformasi Pengalaman Diri di Kabupaten Sidoarjo

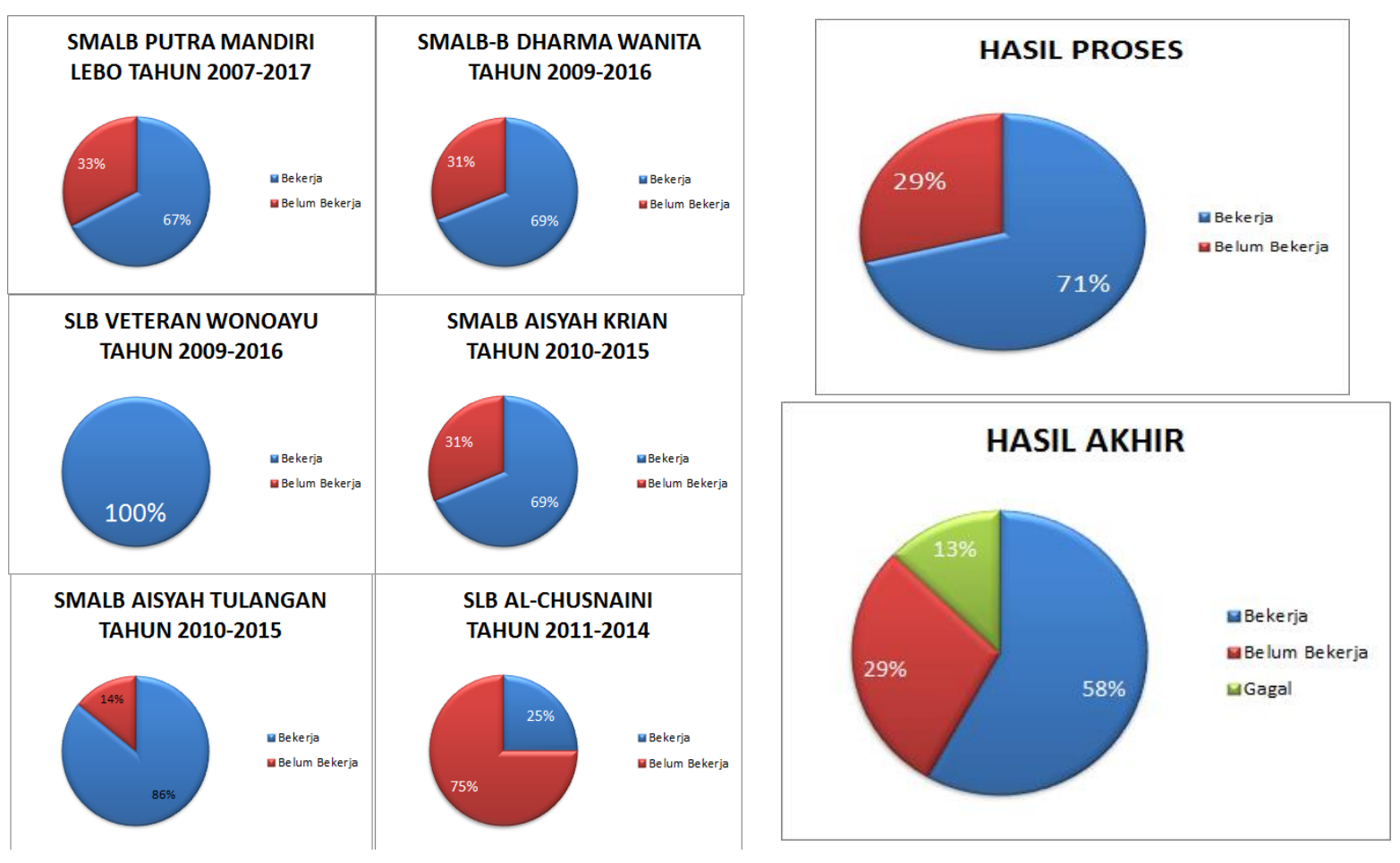

\begin{tabular}{|c|c|c|c|c|c|c|c|}
\hline No. & No. Absensi & Nama Karyawan & Bagian & ASALSEKOLAH & ALAMAT ASAL & NO.TELP/ HP & AGAMA \\
\hline 1 & 12 & Yurika Dyah Kusumawati & Operator Produks Kemas Primer & SLTP YPTB Malang & 11. Paindong Peniwen No.40 Kromengan Malang & 08199141914 & Kristen \\
\hline 2 & 13 & Susiami & Operator Produksi Kemas Sekunder & SMPLB Porong & Bumi Perum Mulya Blok A No. 33 & 083832280996 & Islam \\
\hline 3 & 15 & Novita Aryani & Operator Produksi Kemas Sekunder & SLB Karya Múlya & J1. Sonoke Iing Blok F No.02 sidoarjo & 089615682394 & Kisten \\
\hline 4 & 16 & Nugraheni Fadila Helmi & Operator Produks Kemas Primer & SLB Dharma Wanita Pare & Desa Pliang Kenceng Rt.12 Rw.06 Caruban & 06999466404 & Kristen \\
\hline 5 & 17 & Daniar Nindya Pratama & Operator Produksi Kemas Sekunder & SMALB Putra mandin & Perum Taman Puspa Anggaswangi Blok G1/14 Sukodono Sidoarjo & 082228475313 & Kristen \\
\hline 6 & 18 & Nurul Khoirun Nikmah & Operator Produks kemas Primer & SLB Dharma Wanita Pare & Dsn Karang nongko Ds susuhbang Rt.01 Rw.02 Ringinrejo Kediri & 089687564247 & Islam \\
\hline 7 & 19 & Tri Wahyuni & Operator Produksi Kemas Sekunder & SLB Kemala Bhayangkari 1 & Dsn Krajan Rt.08 RW.03 Karangrejo Kampak Trenggalek & 082333245702 & Kristen \\
\hline 8 & 20 & Fanny Septarini & Operator Produks Kemas Primer & SMALB Putra mandiri & II. Thamrin GG 1 No. 15 Sidoarjo & 089654756621 & Kristen \\
\hline 9 & 21 & Iswati & Operator Produks Kemas Primer & SLB Karya Mulya & d1. Simo gunung 18 No. 07 Surabaya & 089687028305 & Islam \\
\hline 10 & 22 & Yekti Pratiwi & Operator Produksi Kemas Sekunder & SLB Yaat & I1. Tambora Timur Mojosongo Solo & 08960635160 & Islam \\
\hline 11 & 23 & Mundiyanti Punwandari & Operator Produksi Kemas Sekunder & SLB Dharma Wanita & Kurak Candi-Sidoario & 082137777215 & Islam \\
\hline 12 & 24 & Evi Supriyanti & Operator Produksi Kemas Sekunder & SLB Aisyiyah Tulangan & 11. Kyai Achmad Dahlan Rt.01 Rw.04 Tulangan Sidoarjo & 0895321422610 & Islam \\
\hline 13 & 25 & Yuni Dwi Susanti & Operator Produksi Kemas Sekunder & SLB Karya Mulya & J1. Gajah bendo No.12 Kec. Beji Bangil & 085606007709 & Islam \\
\hline 14 & 26 & Link Hardiani & Operator Produksi Kemas Sekunder & SLB Dharma Wanita & J1. Lemah Putro III No. 05 Rt.04 Rw.22 sidoarjo & 0895366790035 & Islam \\
\hline 15 & 28 & Sunarti & Operator Produks Kemas Primer & SLB Lumajang & I1. Brantas No.94 Rt.06 Rw.05 Lumajang & 085730407190 & Islam \\
\hline 16 & 29 & Henny Wijaya & Operator Produks Kemas Primer & SLTA Dena Upakara Wonosobo & 11. Gunung Sari I Gg.1 No.02 Surabaya & 082242668843 & Islam \\
\hline 17 & 31 & Nur Fauziyah & Operator Produksi Kemas Sekunder & SLB Karya Mulya & Kedurus Dukuh I No.22 Surabaya & 082131038739 & Islam \\
\hline 18 & 42 & Wahyu Purnomo & Produksi Gudang & SLB Karya Múya & Griya Permata Hijau Blok X3 No.8 Candi Sidoarjo & $031-8067730$ & Islam \\
\hline 19 & 43 & Sri Cahya Puj̄ Ami & Operator Produksi Kemas Sekunder & SLB Putra Mandin Tarik & Ds. Segodo Bancang Rt.01 n. 01 Tarik & - & Islam \\
\hline 20 & 44 & Imam Saroni & Operator Produksi Pencucian & SLB Dharma Wanita & Plang Wonoayu Sidoarjo & 08563083251 & Islam \\
\hline 21 & 46 & Yulanti Catur Hapsari & Operator Produks Kemas Primer & SLB Karya Mulya & 11. Salak No.05 Rt.02 Rw.01 Geluran Sidoarjo & $08 B 85126940$ & Kristen \\
\hline 22 & 47 & Sri Sugeng & Produksi R \& D & SLB YPAAL B Sukoharjo & Pejalinan Tawangsari Boyolali & 085730325775 & Islam \\
\hline 23 & 49 & Rodiyah & Operator Produksi Kemas Sekunder & SLB Kemala Bhayangkañ 2 & I1. J.A Suprapto Gg.1 N0. 45 BR Gresik & 085704629400 & Islam \\
\hline 24 & 50 & Wiwin Ayu Ferina & Operator Produksi Kemas Sekunder & SLB Karya Mulya & 11. Simomulyo baru 06 No.20 Surabaya & 085600835484 & Islam \\
\hline 25 & 51 & Nurul Sa'adah & Operator Produksi Kemas Sekunder & SLB Kandat Kedir & Desa Jati Udanawu Bitar & 085784587772 & Islam \\
\hline 26 & 62 & Misbahul Munir & Operator Produksi Kemas Sekunder & SLB Bhayangkari & J1. HOS cokroaminoto Trenggalek & 085735626334 & Islam \\
\hline 27 & 69 & Febri Setyawan & Operator Produksi Kemas Sekunder & SLB Negri Gedangan & J1. Kal ibokor Kencana 25 A surabaya & 083832836341 & Kristen \\
\hline 28 & 73 & Sidiq Amruloh & Operator Produksi Kemas Sekunder & SLB Putra Mandiri & Ngasem Rt.12 Rw.06 Kedung Bocok Tarik Sidoarjo & - & Islam \\
\hline 29 & 74 & Lenny Widyastuti & Operator Produksi Kemas Sekunder & SLB Negri Gedangan & J1. Hayam Wuruk 4 Rt.01 Rw.05 Sawotratap Gedangan Sidoarjo & 083834376650 & Islam \\
\hline 30 & 75 & Khoirun Nisa Nur Agustin & Operator Produksi Kemas Sekunder & SLB Negri Gedangan & Suwaluh Selatan Rt.09 Rw.03 Suwaluh Balong Bendo Sidoarjo & 085648779916 & Islam \\
\hline 31 & 76 & Dewi Kunnia Wanti & Operator Produksi Kemas Sekunder & SLB Putra mandiri & 11. Imam Bonjol Rt.06 Rw.02 Geluran Taman Sidoarjo & 089698373681 & Islam \\
\hline 32 & 77 & Siti Aminah & Operator Produksi Kemas Primer & SLB Veteran & Dusun Cangkring Rt.02 Rw.01 Jedong Cangkring Prambon Sidoarjo & 085604568837 & Islam \\
\hline 33 & 78 & Vera Widya Sari & Operator Produksi Kemas Sekunder & SLB Veteran & Ds Grabahan Rt.018 w.03 Kec Tulangan Sidoarjo & 085706005534 & Islam \\
\hline 34 & 79 & Avilia Nur Fitria & Operator Produksi Kemas Sekunder & SLB Al chusnaini & Dusun kedung Kt.23 Rw. 07 Jumputrejo Sukodono Sidoarjo & 081230311178 & Islam \\
\hline 35 & 80 & Katerine Widya Dewanti & Operator Produksi Kemas Sekunder & SLB Al chusnaini & Dusun prumpon Rt.06 Rw.02 Suruh Sukodono Sidoarjo & 083830456712 & Islam \\
\hline 36 & 81 & Ria Andriani & Operator Produks Kemas Primer & SLB Aisyyjyh Tulangan & Balowono Rt.20 RW.10 Wonomlati Krembung Sidoarjo & 083649637974 & Islam \\
\hline 37 & 82 & Eny Kurnia Dewi & Operator Produks Kemas Primer & SLB Putra Mandiri & Dusun Ngembul Rt.021 Rw.03 Jombok Ngantang Malang & 085731137670 & | Islam \\
\hline
\end{tabular}

Data lulusan yang bekerja di PT. UFI 
DISSABILITY WORKERS

PT YOUNG TREE INDUSTRIES

April 2017

\begin{tabular}{|c|c|c|c|c|c|c|}
\hline No & No Abs & NAMA & Jenis Kelamin & Dept & Bagian & Tgl masuk \\
\hline 1 & 1607256624 & LASIONO & Laki-Laki & STITCHING & MOCASIN & $2016 / 7 / 11$ \\
\hline 2 & 1607256024 & MOCH BAHRUL ULUM & Laki-Laki & STITCHING & MOCASIN & $2016 / 7 / 11$ \\
\hline 3 & 1607252624 & MOCH RUSLAN & Laki-Laki & STITCHING & MOCASIN & $2016 / 7 / 11$ \\
\hline 4 & 1607256124 & SUWITO TJANDRA & Laki-Laki & STITCHING & JAHIT SOLE & $2016 / 7 / 11$ \\
\hline 5 & 1607256524 & ADI WAHYUDI & Laki-Laki & STITCHING & E4 & $2016 / 7 / 11$ \\
\hline 6 & 1607253424 & SHOFIYATUL MUNIROH & Perempuan & STITĆHING & E2 & $2016 / 7 / 11$ \\
\hline 7 & 1607253024 & NINDY KRISTIANA PUTRI & Perempuan & STITCHING & E10 & $2016 / 7 / 11$ \\
\hline 8 & 1607256324 & YUDHI ARI WIJAYA & Laki-Laki & STITCHING & D1 & $2016 / 7 / 11$ \\
\hline 9 & 1607256224 & MOCH SOFIE & Laki-Laki & STITCHING & E2 & $2016 / 7 / 11$ \\
\hline 10 & 1607252524 & ABRAHAM AGUSTIAN ELDO & Laki-Laki & MIDSTORE & PPCC & $2016 / 7 / 11$ \\
\hline 11 & 1609028824 & NUKI NURAINI & Perempuan & LASTING & ASS H1 & $2016 / 9 / 7$ \\
\hline 12 & 1607255924 & SENIA FERIMA NAYSILA & Perempuan & LASTING & ASS FINISH & $2016 / 7 / 11$ \\
\hline 13 & 1609026524 & DHIKA PRASETYA & Perempuan & LASTING & ASS E3 & $2016 / 9 / 6$ \\
\hline 14 & 1609037724 & IKA FEBRIANA & Perempuan & LASTING & ASS D3 & $2016 / 9 / 19$ \\
\hline 15 & 1609039224 & TRI WIJI SUBEKTI & Laki-Laki & LASTING & ASS C3 & $2016 / 9 / 19$ \\
\hline 16 & 1609033724 & WIDODO DWI HADI YANTO & Laki-Laki & LASTING & ASS C 3 & $2016 / 9 / 19$ \\
\hline 17 & 1609034524 & URSULA FITRIANI & Perempuan. & LASTING & ASS C1 & 2016/9/19 \\
\hline 18 & 1607253224 & ABDUL MALIK & Laki-Laki & LASTING & ASS B1 & $2016 / 7 / 11$ \\
\hline 19 & 1607256724 & MOCH ANWARI AL DJUFRI & Laki-Laki & HR & CLEANING SERVICE & $2016 / 7 / 11$ \\
\hline 20 & 1607256424 & SYAFIQ HAQIQI & Laki-Laki & DEPOT & O SOLE A2 & $2016 / 7 / 11$ \\
\hline 21 & 1607253324 & INDAH NOVITA SARI & Perempuan & DEPOT & M SOLE LINE D & $2016 / 7 / 11$ \\
\hline 22 & 1607252724 & SUNARTO & Laki-Laki & DEPOT & M SOLE A & $2016 / 7 / 11$ \\
\hline
\end{tabular}

s-

Sidoarjo, 30 April 2017

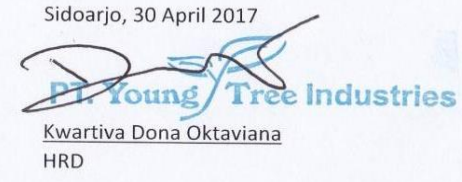

Data lulusan yang bekerja di PT. Young Tree

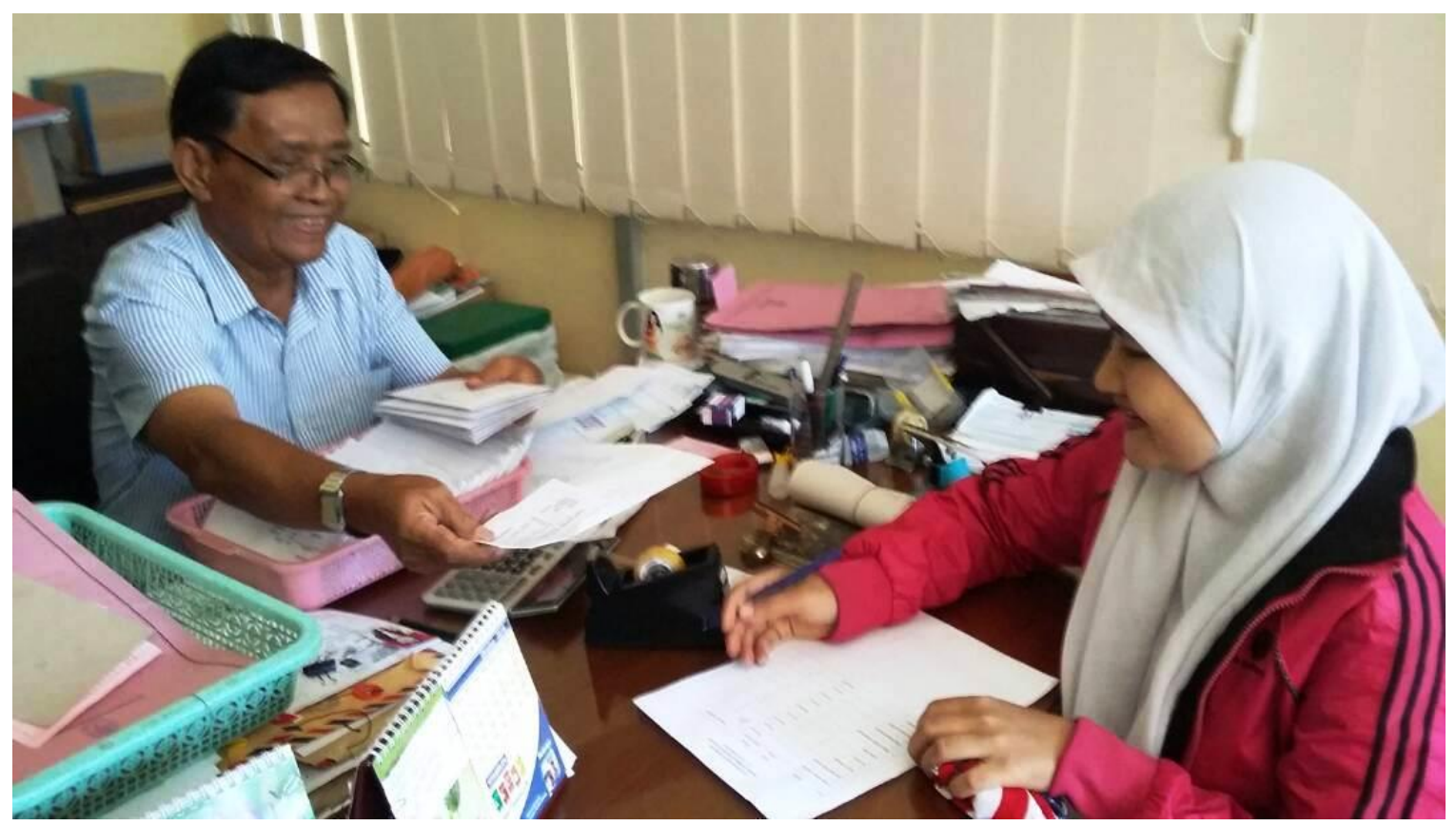

Penerimaan gaji di PT. First Medipharma 


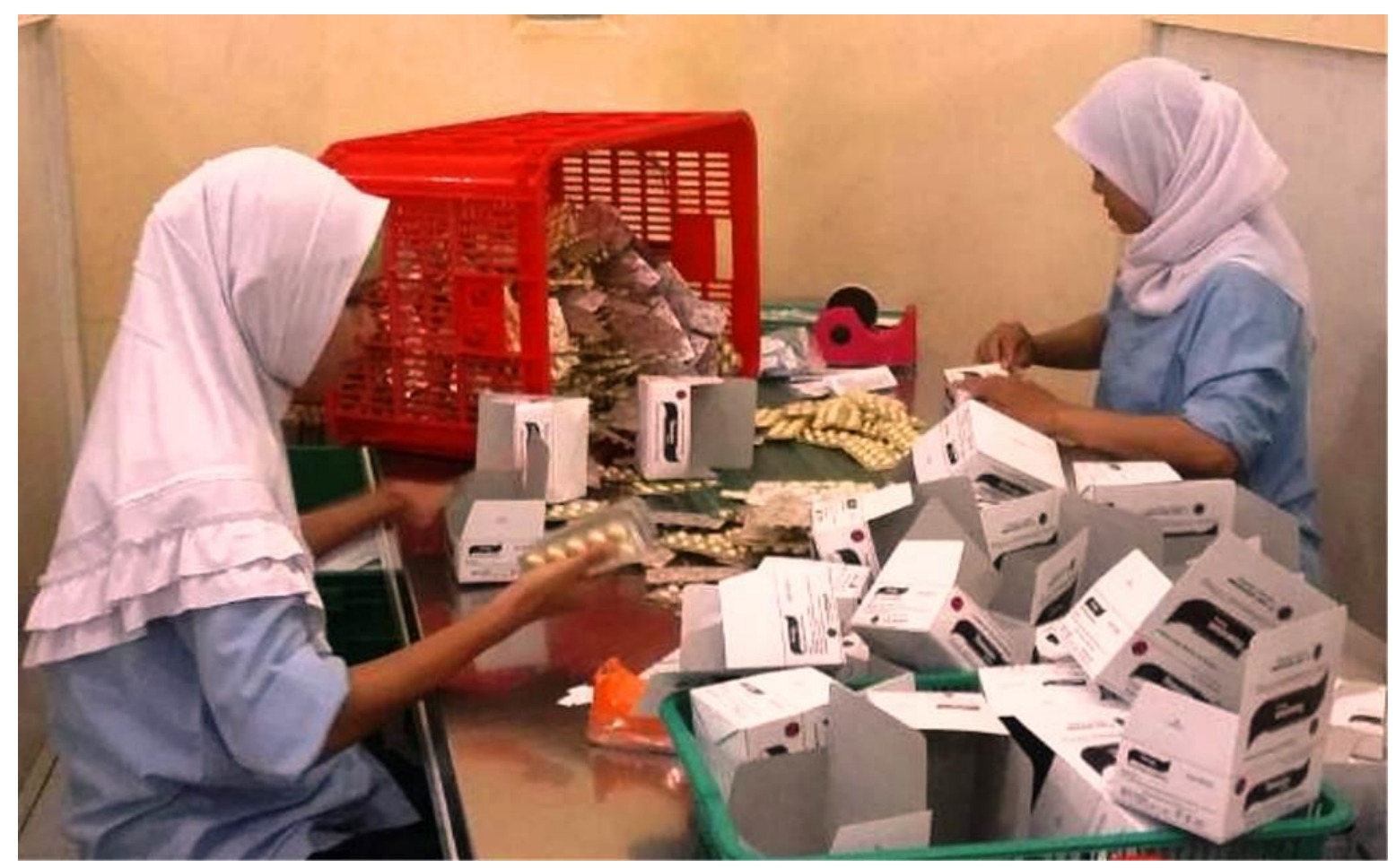

Packaging di PT. First Medipharma

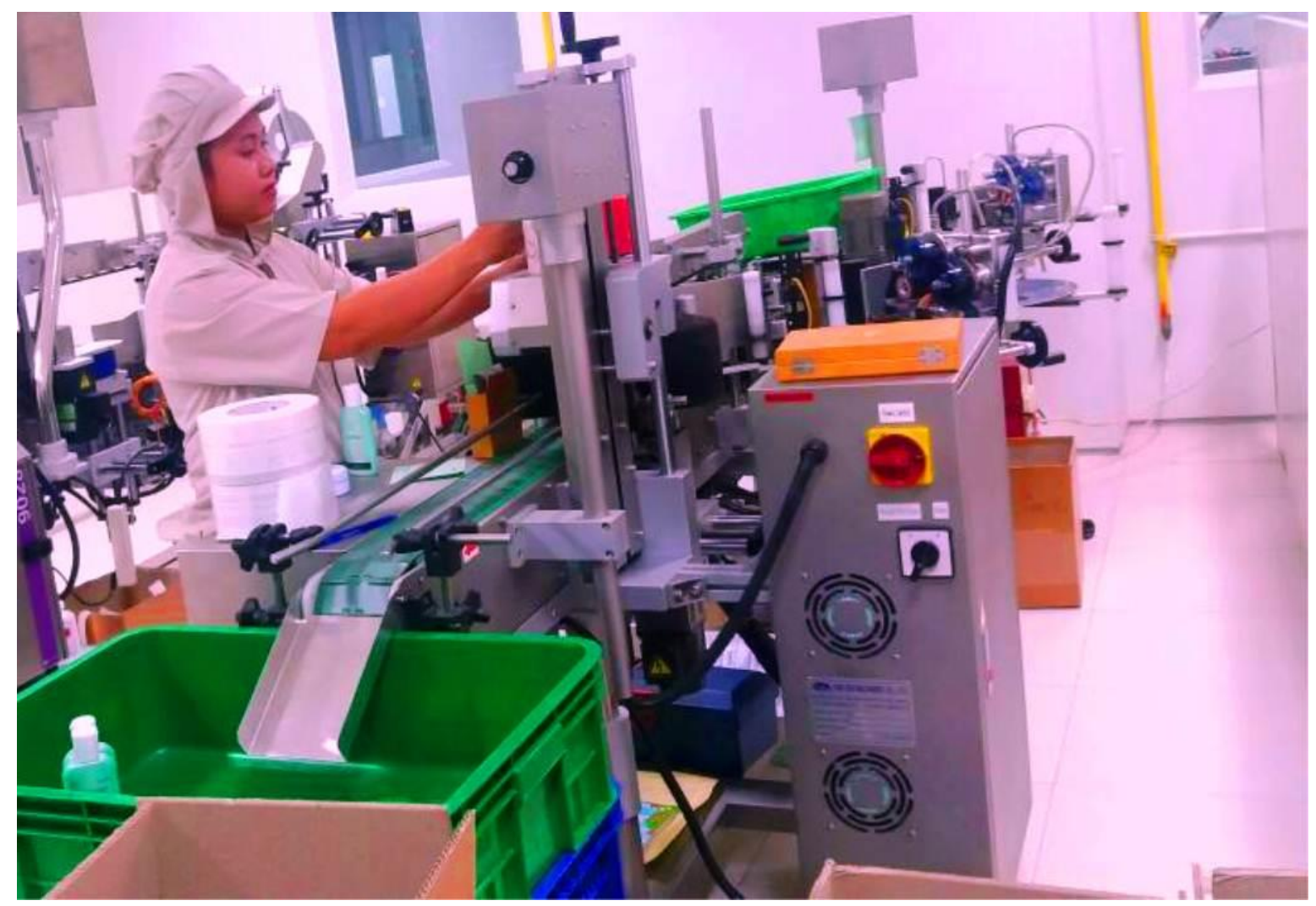

Lulusan SMALB yang bekerja di PT. UFI 


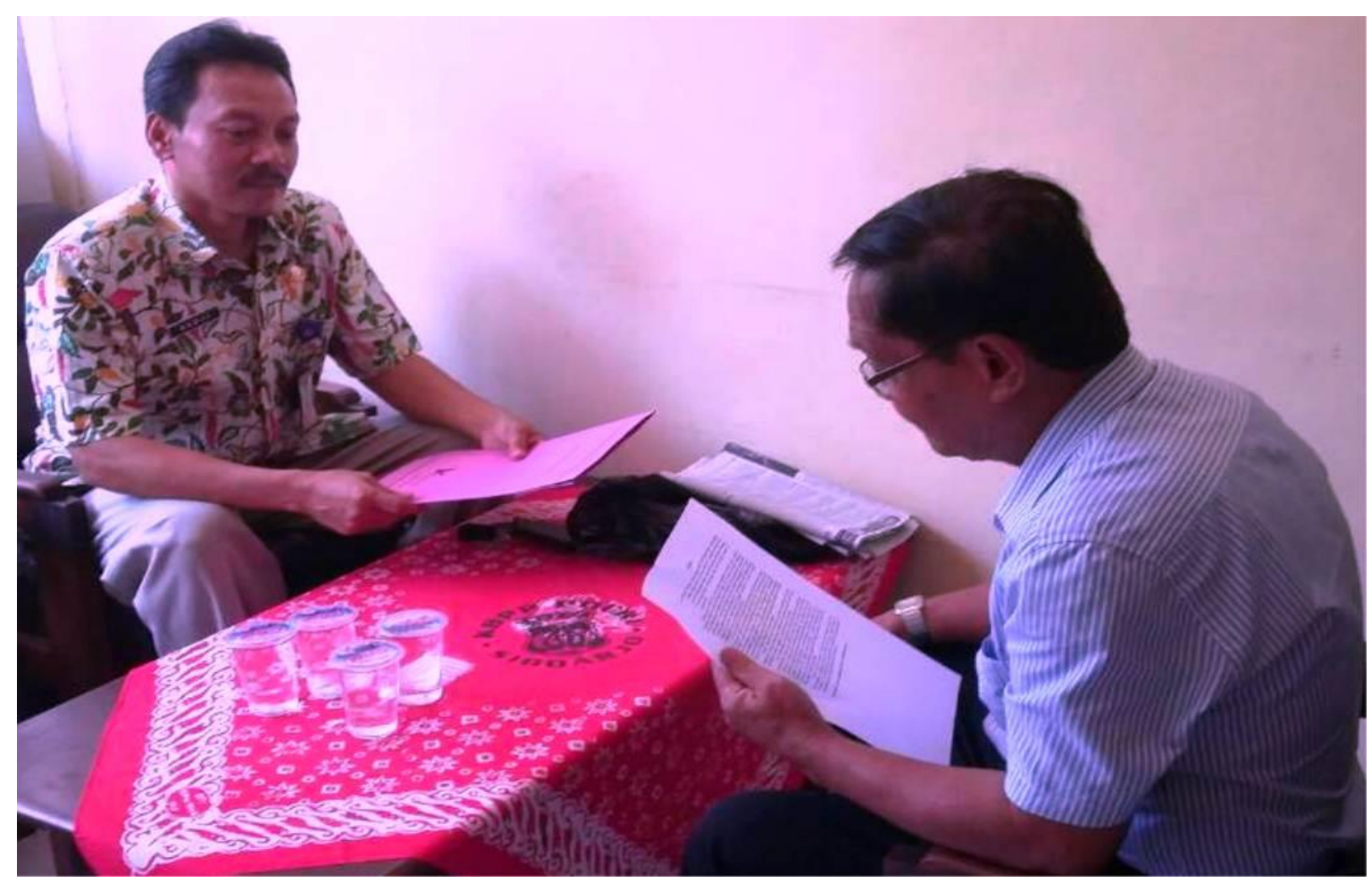

MOU dengan PT. First Medipharma

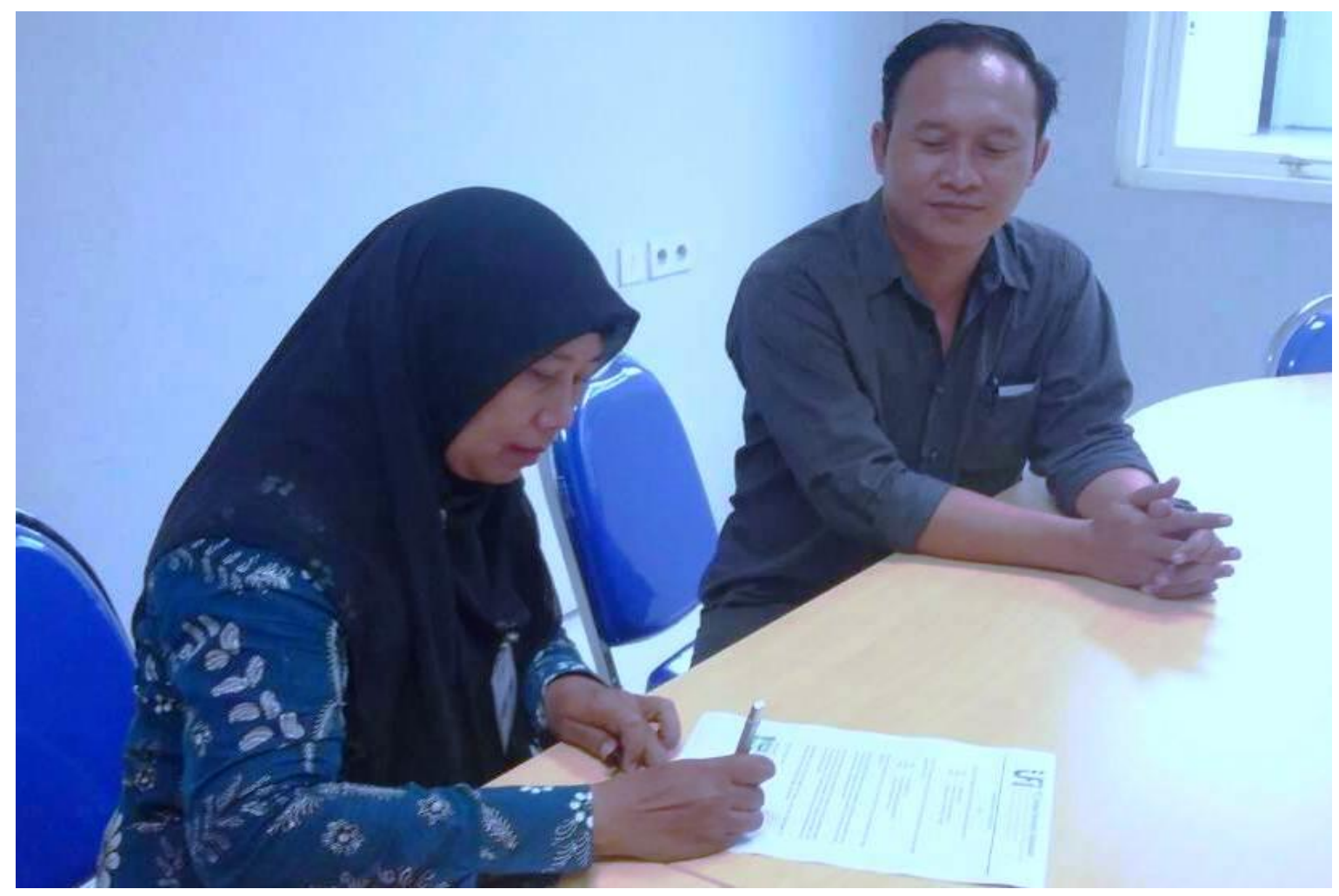

MOU dengan Manager PT. UFI 
Pembinaar Knmnotonci Kowivaucahnan Konaln Solnnlah Molnlui Transformasi Pengalaman Diri di Kabupaten

Sidoarjo

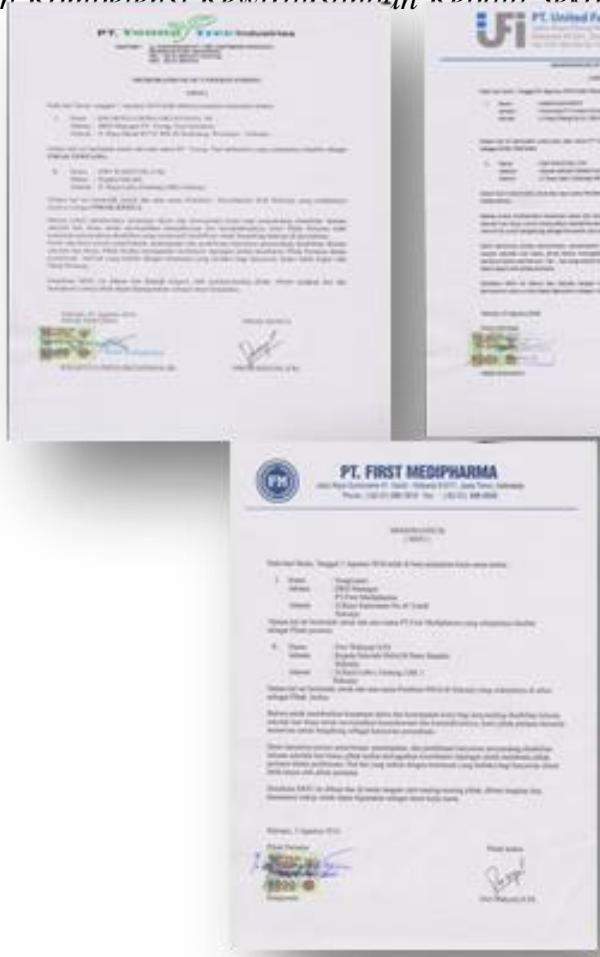

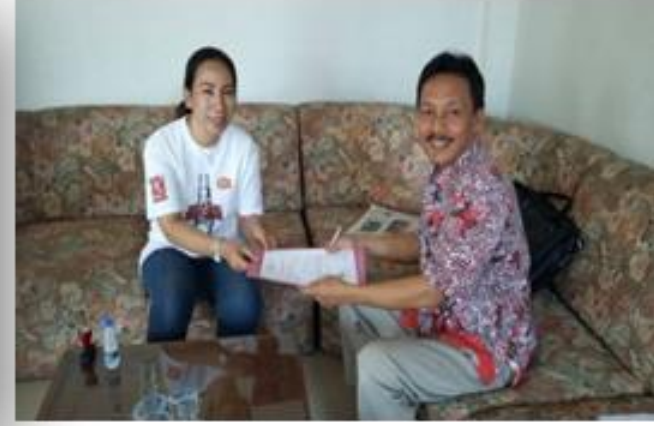

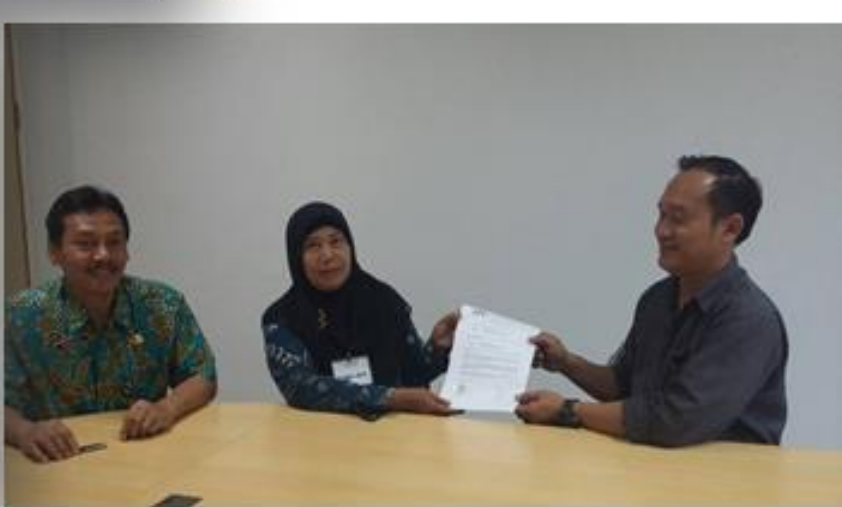

MOU dengan PT. Young Tree

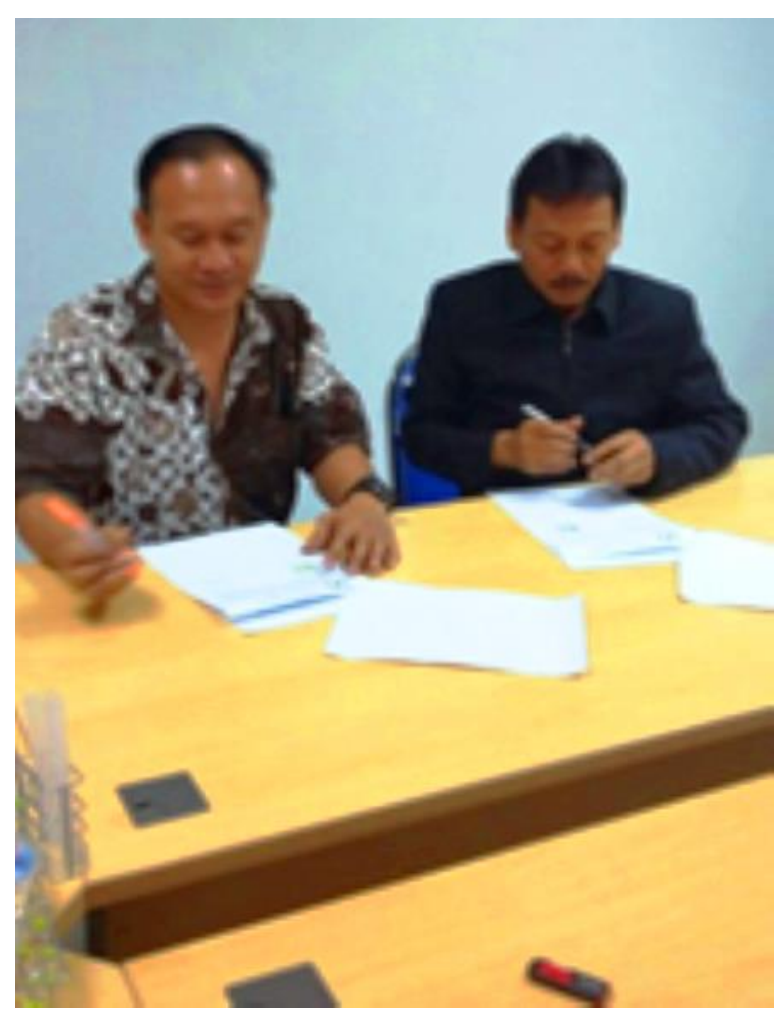

MOU dengan PT. UFI
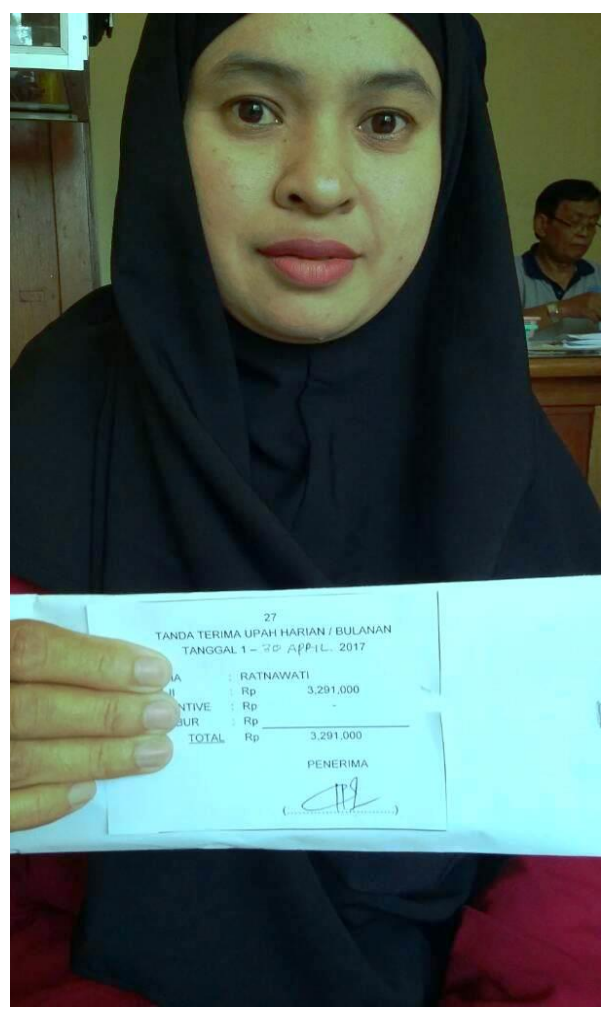

Karyawan menerima gaji 


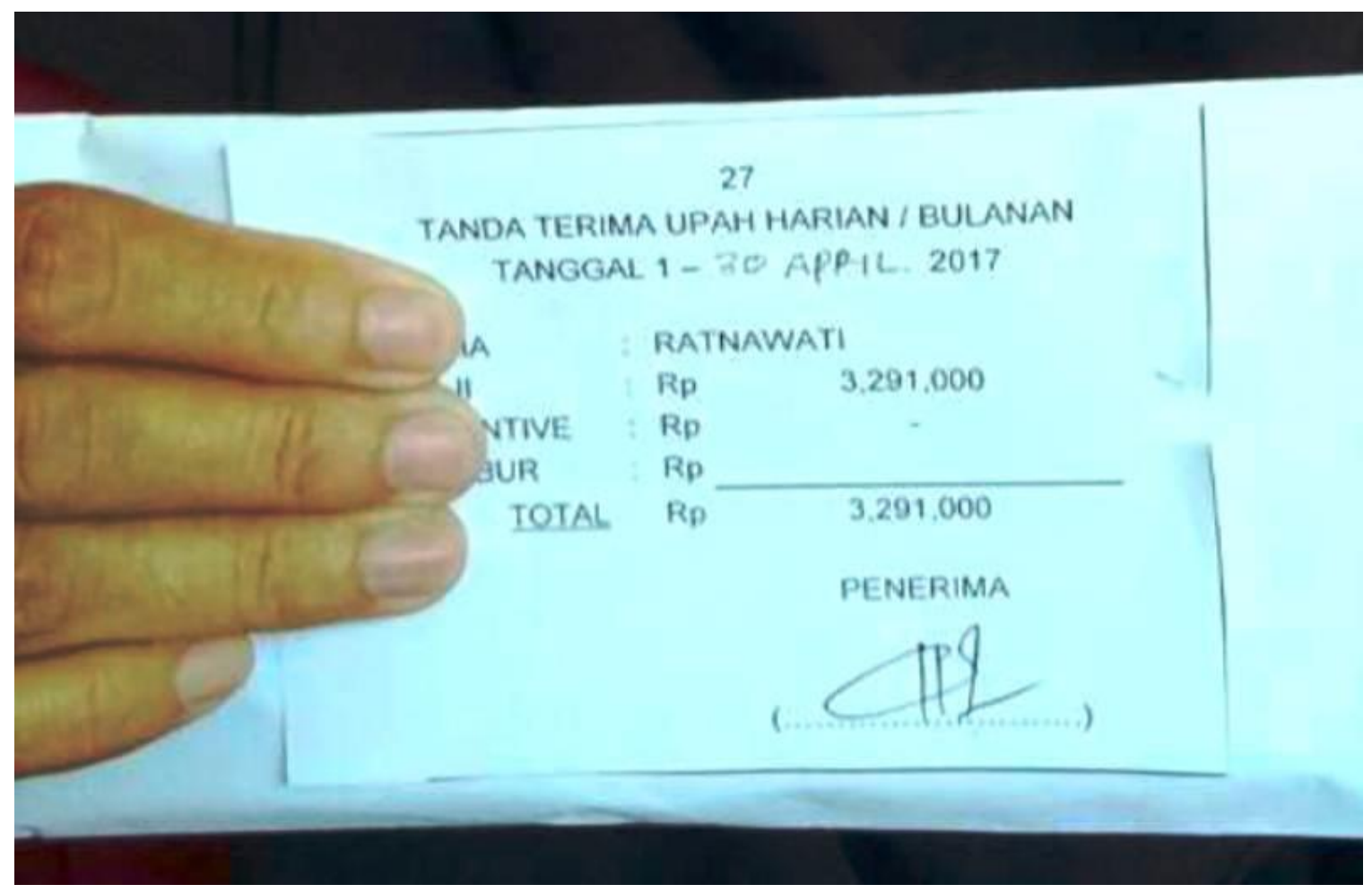

Gaji karyawan dari alumni SLB

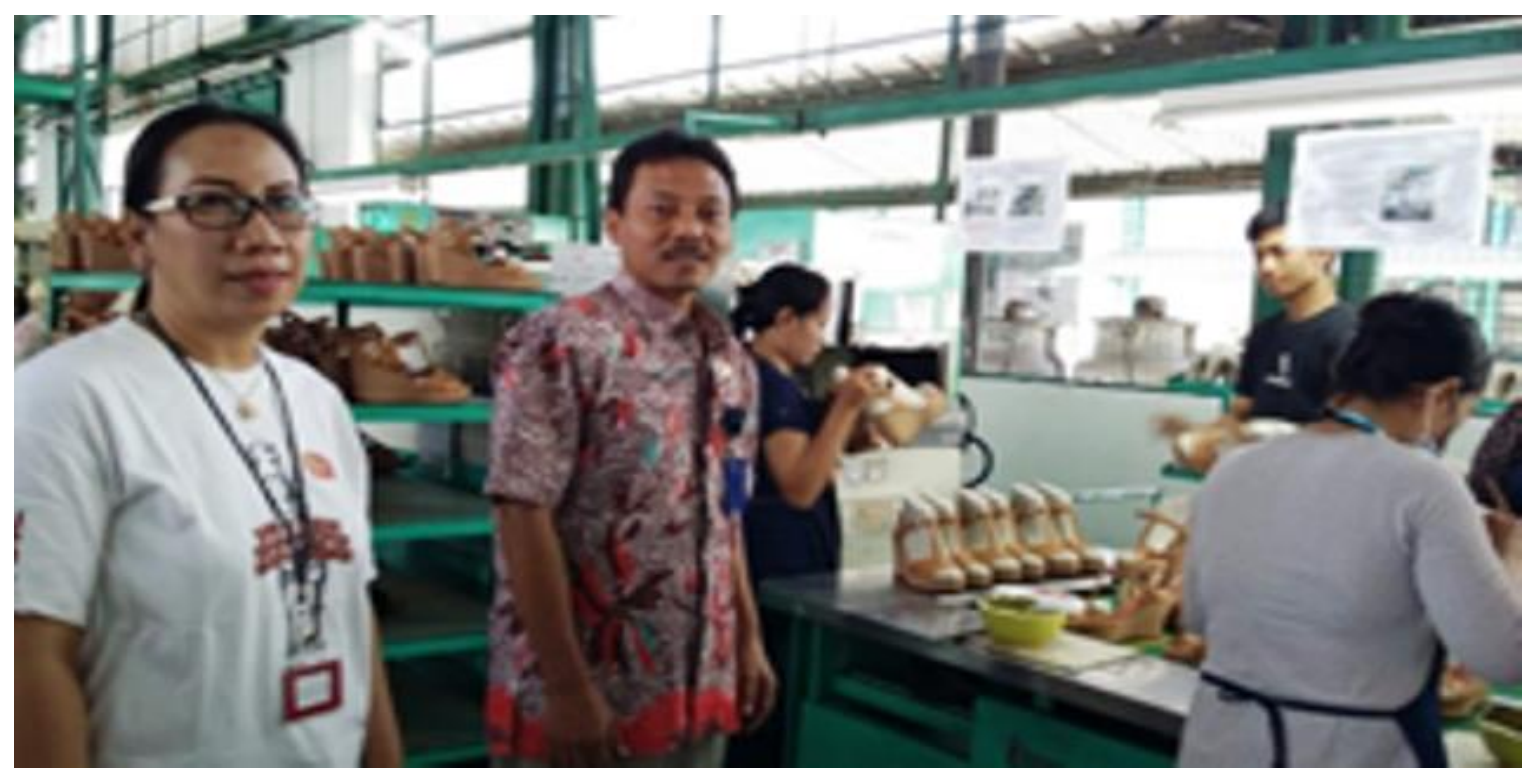

Monitoring bersama PT. Young Tree 


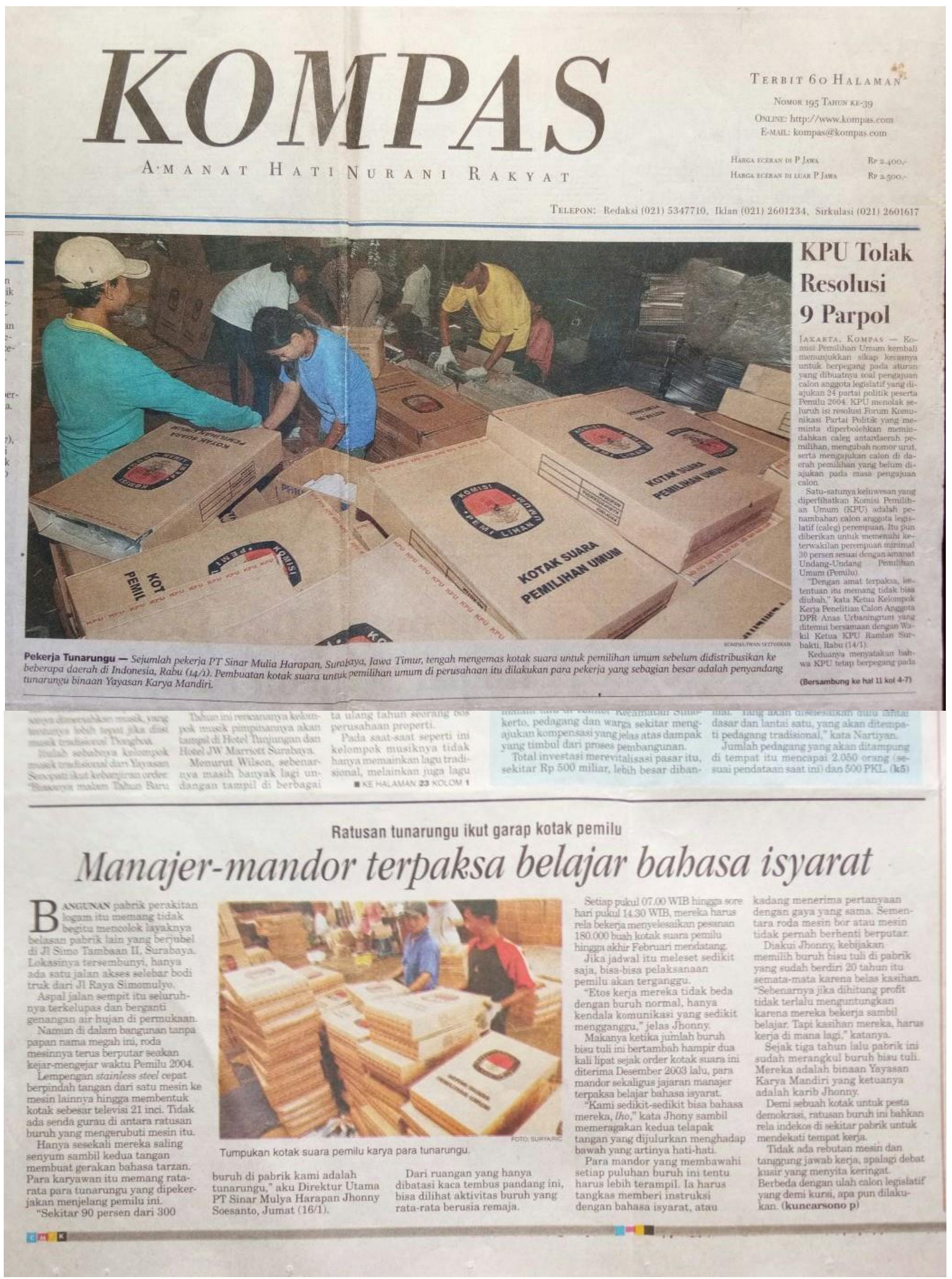

Penyaluran lulusan di PT Sinar Mulya Harapan Surabaya 


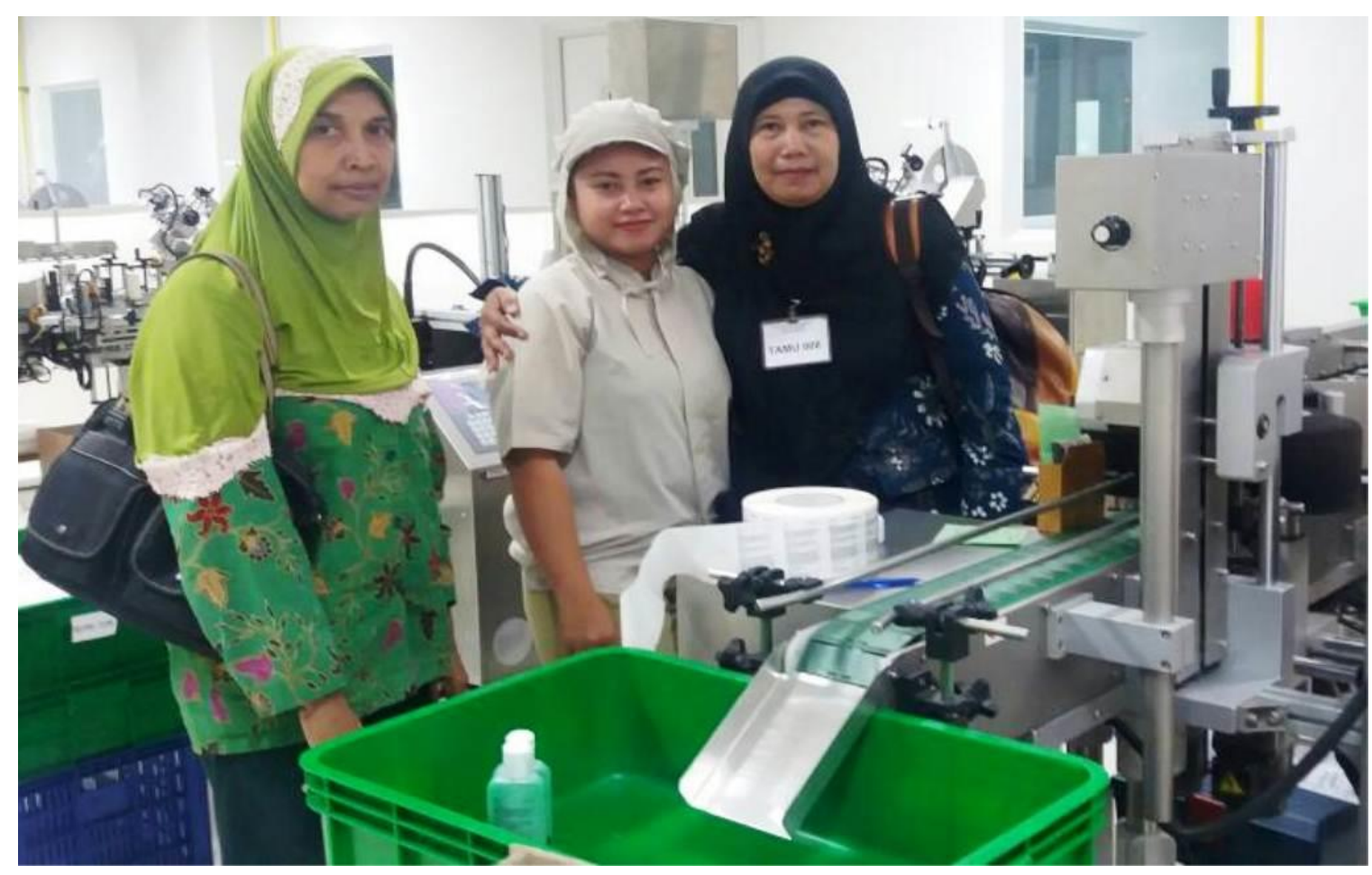

Monitoring di PT. UFI

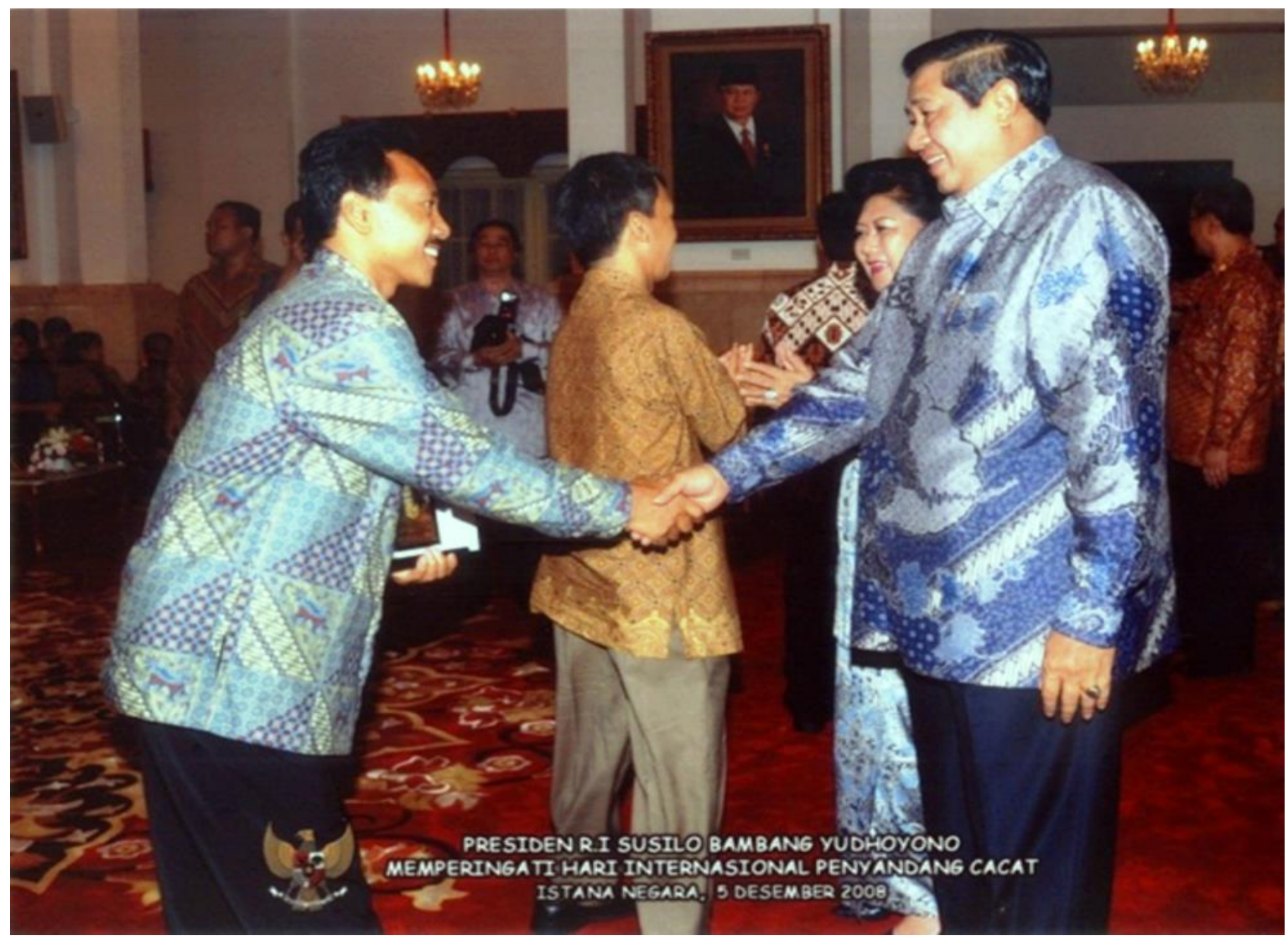

Mendapat Ucapan selamat dari Bapak Presiden Susilo Bambang Yudoyono 


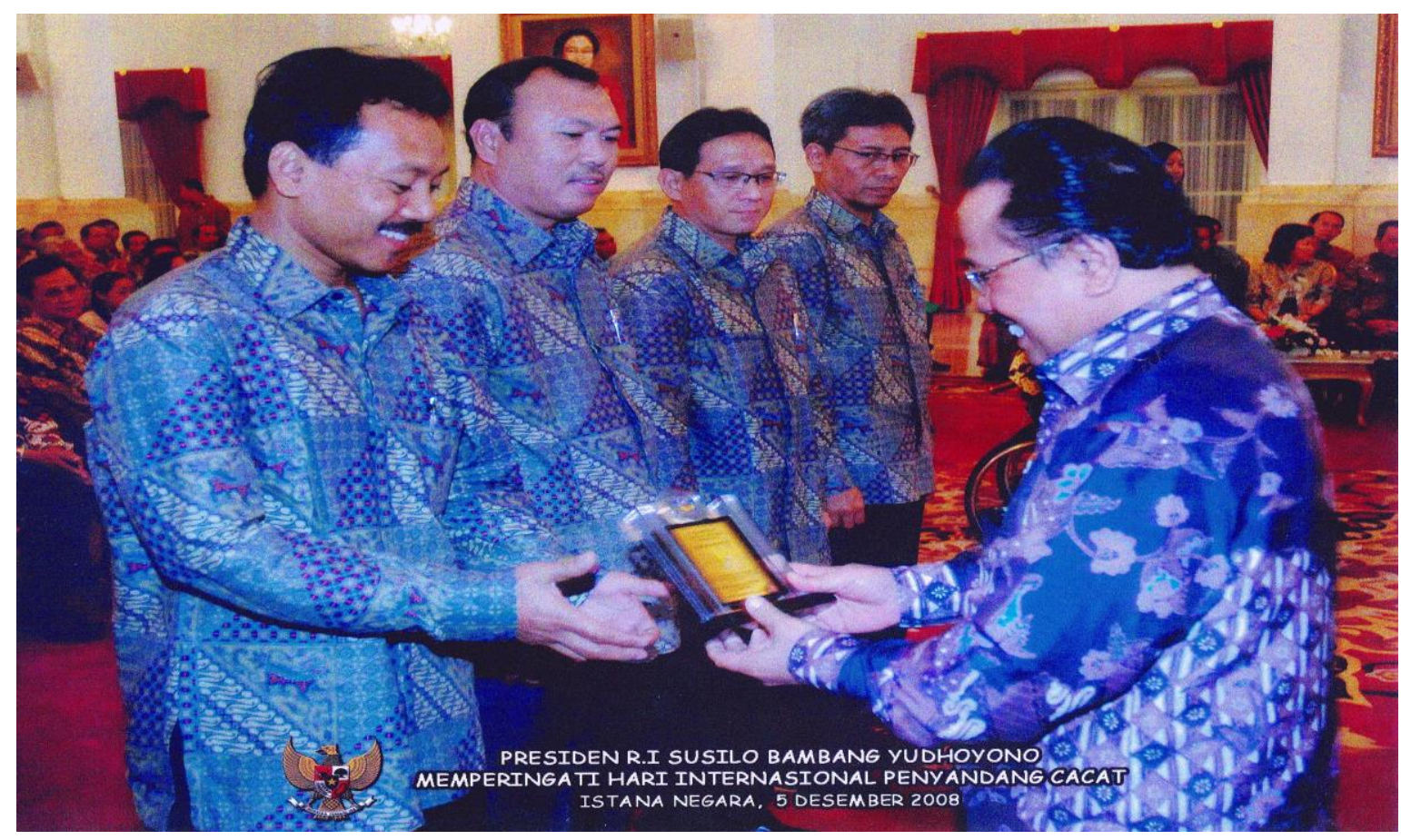

Menerima plakat dari Menteri Tenaga Kerja dan Transmigrasi

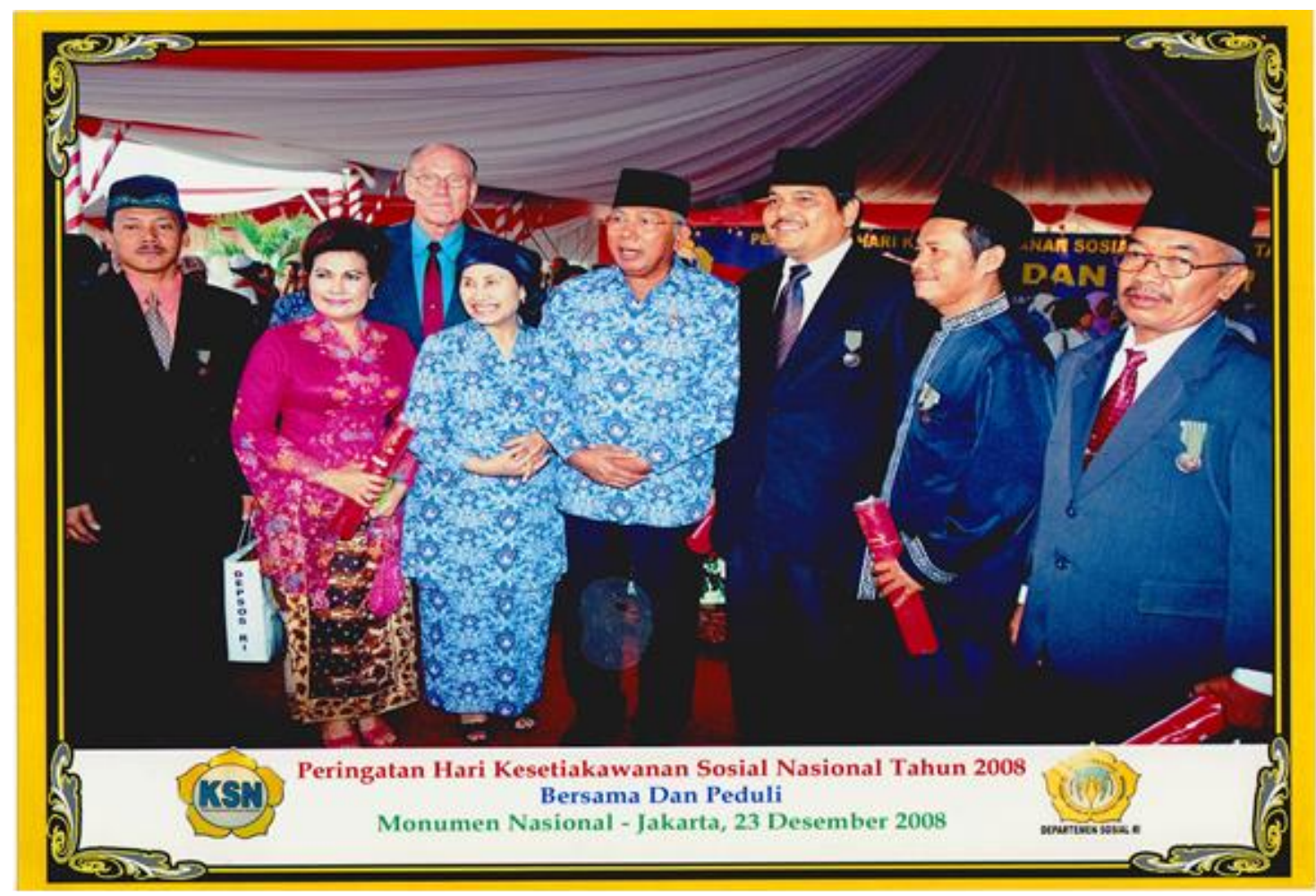

Diundang kementrian social dalam peringatan HKSN 